Portland State University

PDXScholar

\title{
Analysis of Mitochondrial DNA Restriction Fragment Patterns in Killer Whales, Orcinus Orca
}

Tracy Alison Stevens

Portland State University

Follow this and additional works at: https://pdxscholar.library.pdx.edu/open_access_etds

Part of the Animal Sciences Commons, Biology Commons, and the Genetics Commons Let us know how access to this document benefits you.

\section{Recommended Citation}

Stevens, Tracy Alison, "Analysis of Mitochondrial DNA Restriction Fragment Patterns in Killer Whales, Orcinus Orca" (1989). Dissertations and Theses. Paper 3928.

https://doi.org/10.15760/etd.5812

This Thesis is brought to you for free and open access. It has been accepted for inclusion in Dissertations and Theses by an authorized administrator of PDXScholar. Please contact us if we can make this document more accessible: pdxscholar@pdx.edu. 
AN ABSTRACT OF THE THESIS OF Tracy Alison stevens for the Master of Science in Biology presented April 28, 1989.

Title: Analysis of Mitochondrial DNA Restriction Fragment Patterns in killer whales, orcinus orca.

APPROVED BY THE MEMBERS OF THE THESIS COMMITTEE:

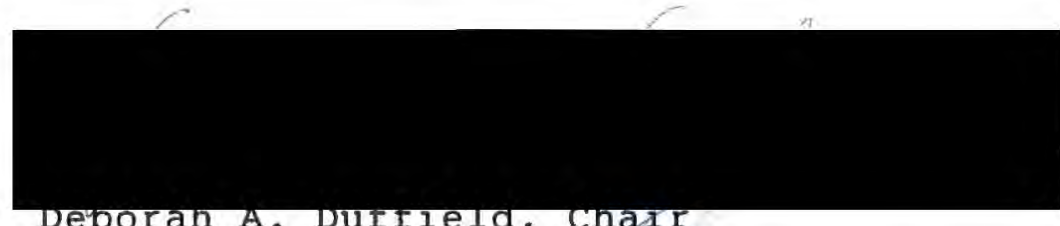

Deboran A. DuIIIeId, char

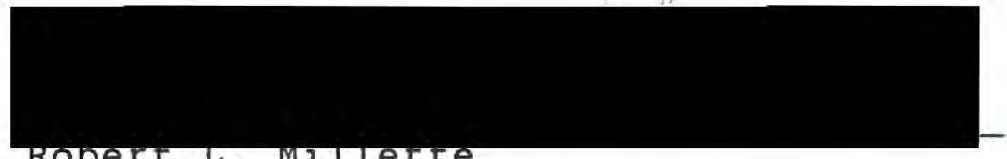

Rolort L. MIIIecte
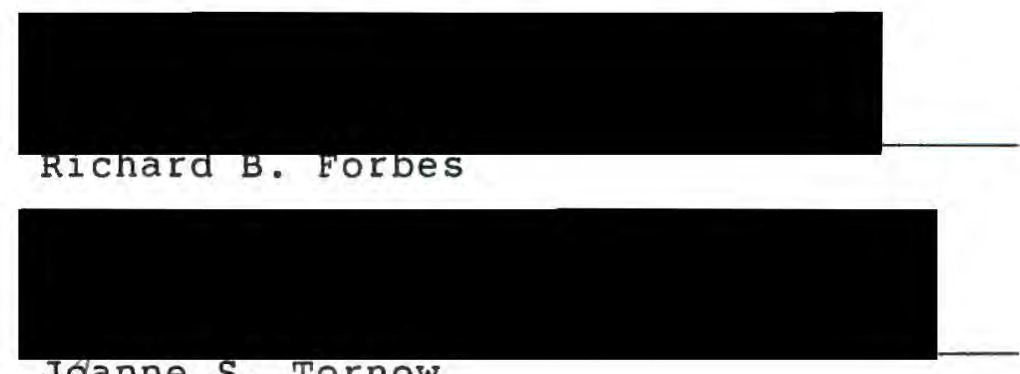

Joganne S. Tornow

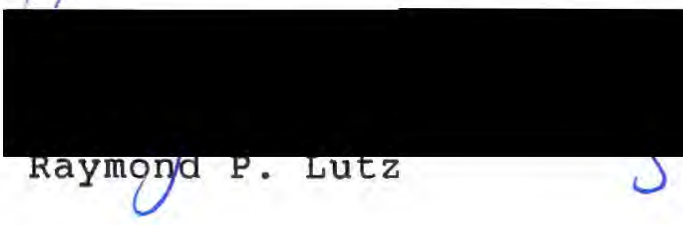

The mitochondrial DNA restriction fragment patterns

of killer whales (Orcinus orca) were investigated in order

to determine the level of genetic differentiation that

exists between killer whales from various geographic

locations. Twenty one killer whales were examined, 
seventeen of which were captive killer whales that originated from the North Atlantic and Northeast Pacific oceans. Two were captive-born animals and two were killer whales that stranded along the Northeast Pacific coast. DNA was extracted from blood and/or tissue samples, cleaved with a variety of restriction endonucleases and the DNA fragments were separated by horizontal agarose gel electrophoresis. The DNA was then transferred to nylon membranes and the killer whale mitochondrial DNA was visualized by hybridization to the complete mitochondrial DNA genome of Commerson's dolphin (Cephalorhynchus commersonii). The resultant restriction fragment patterns were analyzed to determine whether mitochondrial DNA variation was present between killer whales from different geographic regions or between communities and pods of killer whales from the same geographic location.

The level of mitochondrial DNA restriction fragment polymorphism between killer whales was low in comparison to other mammalian species. Of the fourteen restriction endonucleases utilized, only three exhibited variability between killer whales. Two of these enzymes, Saug6 I and Alu I, were effective in differentiating killer whales that originated from the Pacific transient community from all other killer whales used in the study. The enzyme Hae III divided the animals into three groups: 1) killer whales originating from the Atlantic ocean; 2) those from the 
Pacific resident community and 3) those of the Pacific transient community.

The mitochondrial DNA genome was estimated to be $16,600 \pm 400$ base pairs in length. The positions of the restriction sites for the enzymes Ava I, BamH I, Bgl II and Pvu II were mapped relative to one another on the killer whale mitochondrial DNA genome.

Several hypotheses are put forward to help explain why variation in the killer whale mitochondrial DNA restriction fragment patterns was so low and to provide possible reasons for the separation of the killer whales into Atlantic, Pacific resident and Pacific transient groups by mitochondrial DNA type. A model of the possible evolutionary relationships between killer whales that may have led to the observed mitochondrial DNA restriction fragment patterns is presented. 


\title{
ANALYSIS OF MITOCHONDRIAL DNA RESTRICTION FRAGMENT
}

PATTERNS IN KILLER WHALES, ORCINUS ORCA

by

TRACY ALISON STEVENS

A thesis submitted in partial fulfillment of the requirements for the degree of

\author{
MASTER OF SCIENCE \\ in \\ BIOLOGY
}

\author{
Portland state University \\ 1989
}


TO THE OFFICE OF GRADUATE STUDIES:

The members of the Committee approve the thesis of Tracy Alison Stevens presented April 28, 1989.

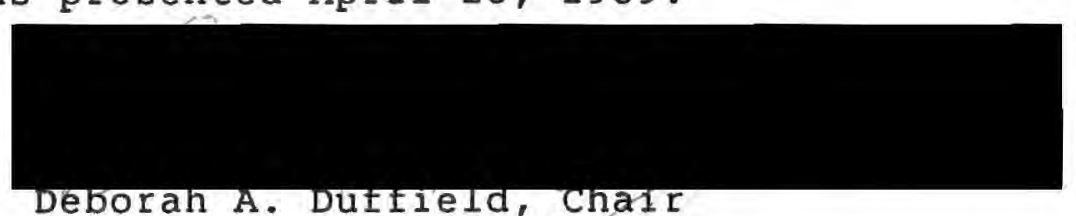

Deborah A. Duffield, Char

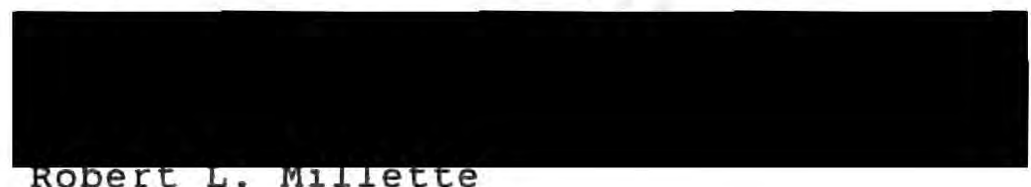

Robert L. Mrllette

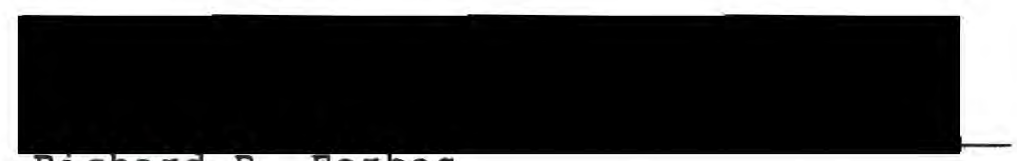

Richard B. Forbes

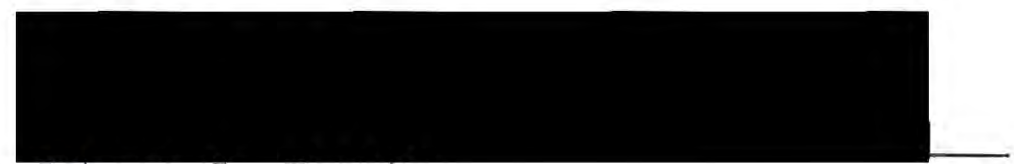

Joanne S. Tornow

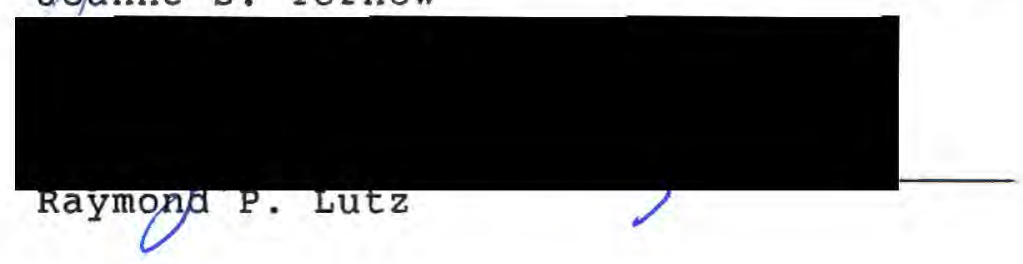

AP PROVED :
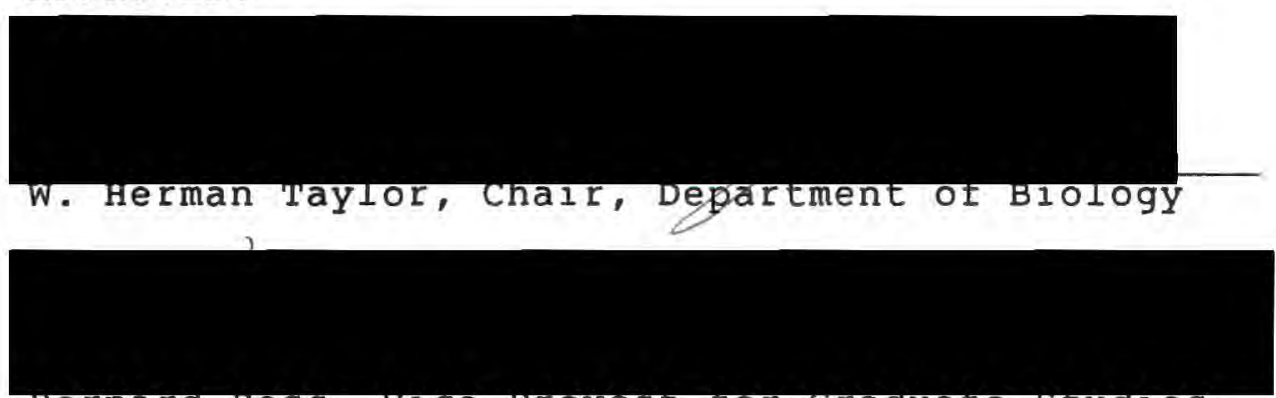

Bernara Ross, vice provost ror Graduate studies 


\section{ACKNOWLEDGEMENTS}

My love to my family, who was always there to listen and provide moral support when I needed it. I would like to express my gratitude to Debbie Duffield, my advisor and friend, whose enthusiasm and belief in this study helped me make it through. Special thanks to sarka southern for providing the Commerson's dolphin probe and to Patricia Perry, Mehrdad Farahmand and kelly Thomas for their help during technical difficulties. I am indebted to the following oceanaria for providing blood and tissue samples when necessary: Sea World of Florida, Sea World of California, Vancouver Public Aquarium, Sealand of the Pacific, Marine World Africa USA and Miami Seaquarium. This study was funded in part by a grant from HBJ Parks, Inc. 
TABLE OF CONTENTS

PAGE

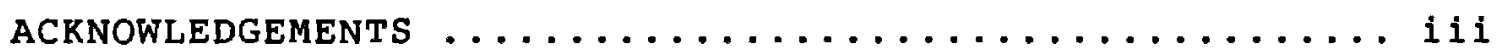

LIST OF TABLES $\ldots \ldots \ldots \ldots \ldots \ldots \ldots \ldots \ldots \ldots \ldots \ldots$ vii

LIST OF FIGURES $\ldots \ldots \ldots \ldots \ldots \ldots \ldots \ldots \ldots \ldots \ldots \ldots \ldots \ldots \ldots \ldots \ldots$

INTRODUCTION $\ldots \ldots \ldots \ldots \ldots \ldots \ldots \ldots \ldots \ldots \ldots \ldots \ldots \ldots \ldots \ldots$

Killer Whales $\ldots \ldots \ldots \ldots \ldots \ldots \ldots \ldots \ldots \ldots \ldots$

Distribution ................... 1

systematics ................. 3

Geographic variation ..............

Killer whales of the Vancouver

Island Region .............. 4

Mitochondrial DNA $\ldots \ldots \ldots \ldots \ldots \ldots \ldots \ldots \ldots \ldots$

Genome size, structure and content ....... 14

Replication ................... 17

The Displacement Loop .............. 18

Genetic Code .................. 19

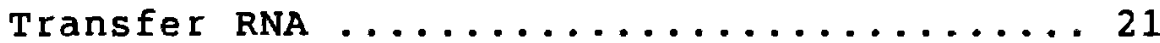

Size variation .................... 22

Nucleotide Sequence Evolution ..........23

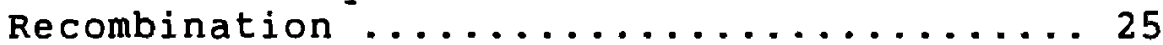

Rapid Rate of Mitochondrial DNA Evolution . 25

Mitochondrial DNA Inheritance .........28

The Use of Mitochondrial DNA in

Population Genetics ............ 29

Goals of the study ................. 31

MATERIALS AND METHODS $\ldots \ldots \ldots \ldots \ldots \ldots \ldots \ldots \ldots \ldots \ldots$

Study Animals ..................... 33

Sampling and Extraction Procedures ......... 36

Mitochondrial DNA Probe $\ldots \ldots \ldots \ldots \ldots \ldots \ldots \ldots 38$

Preparation of Mitochondrial DNA Probe ... 38 
Biotin Labelling of Mitochondrial

DNA Probe ................ 40

Radioactive Labelling of Mitochondrial

DNA Probe .................4 42

Southern Transfer Procedure $\ldots \ldots \ldots \ldots \ldots \ldots \ldots 42$

Restriction Endonucleases ...........4 42

Gel Electrophoresis .............. 45

Southern Transfer .............. 47

Restriction Fragment Analysis ...........48

Fragment size Determination .........4 48

Mapping of the Mitochondrial DNA Genome ... 49

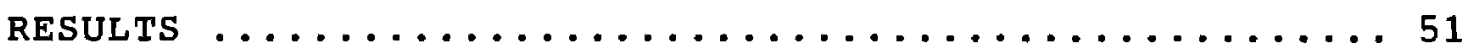

Restriction Fragment Patterns ............ 51

Invariant Restriction Fragment Patterns ... 51

Restriction Fragment Pattern Variation .... 55

Hind III Restriction ..............6 64

Genome size Estimation ................65

Map of the Killer whale Mitochondrial

DNA Genome .................... 65

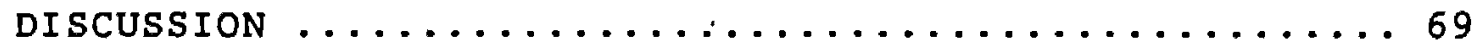

Population Characterization $\ldots \ldots \ldots \ldots \ldots \ldots 9$

Mitochondrial DNA Variability .........70

Mitochondrial DNA Lineage Extinction .....773

Mitochondrial DNA Evolutionary Rate ......74

Intraspecific Phylogeography ..........75

Chromosomal Evolution in killer whales ....79

Dominance Hierarchies Among Killer Whales .80

A Model of Killer whale Evolution $\ldots \ldots \ldots \ldots \ldots 81$

HIND III Star Activity and Inactivation .......84

Future Genetic Analysis of Killer whales ......85

CONCLUSIONS $\ldots \ldots \ldots \ldots \ldots \ldots \ldots \ldots \ldots \ldots \ldots \ldots \ldots$

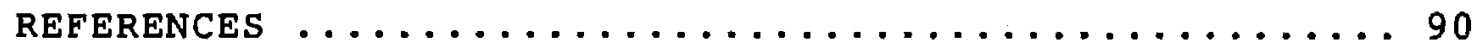


A Total DNA Extraction from Blood ........ 100

B Mitochondrial DNA Extraction from Blood ... 102

C Rapid Mitochondrial DNA Isolation from Tissue .................. 104

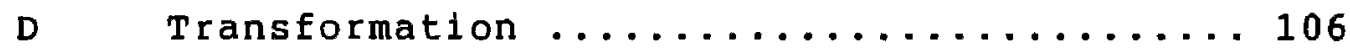

E Plasmid Preparation .............. 108

F Spun Column Procedure ............ 112

G Trichloroacetic Acid Precipitation of Nucleic Acids ............... 113

H Southern Transfer .............. 114 


\section{LIST OF TABLES}

TABLE

PAGE

I Killer Whales Used in This study Listed

by Capture Date and site, Sex and

Tissue Type Used to obtain

Mitochondrial DNA Samples ........ 34

I Recognition Sequences of Restriction

Endonucleases Utilized in the

study ....................... 44 


\section{LIST OF FIGURES}

F IGURE

PAGE

1. The Worldwide Distribution of Killer

whales .................... 2

2. Identification Photographs of Two Killer

Whales From the Vancouver Island

Region $\ldots \ldots \ldots \ldots \ldots \ldots \ldots$

3. Map of Vancouver Island Region .......... 9

4. Genetic Map of the Human MtDNA Molecule ... 16

5. Location of Live-capture and stranding

Sites for Pacific Killer Whales .... 35

6. Restriction Map of Cloned sites on the

MtDNA Molecule of Cephalorhynchus

commersonii, Commerson's Dolphin... 39

7. DNA Used to Determine Fragment sizes of

Restricted MtDNA ............. 46

8. Invariant Restriction Fragment Profiles of

Killer Whale MtDNA ............ 53

9. Restriction Fragment Profile of Killer

Whale MtDNA Cleaved with the Enzyme

Hha $I \ldots \ldots \ldots \ldots \ldots \ldots \ldots \ldots \ldots$

10. Invariant Restriction Fragment Profiles of

Killer Whale MtDNA .......... 56 
11. Restriction Fragment Profile of Killer Whale MtDNA Cleaved with the Enzyme Rsa $I \ldots \ldots \ldots \ldots \ldots \ldots \ldots \ldots \ldots$

12. Restriction Fragment Profile of Killer Whale MtDNA Cleaved with the Enzyme Hae III $\ldots \ldots \ldots \ldots \ldots \ldots \ldots \ldots \ldots$

13. Restriction Fragment Profile of Killer Whale MtDNA Cleaved with the Enzyme Hae III $\ldots \ldots \ldots \ldots \ldots \ldots \ldots \ldots \ldots \ldots \ldots \ldots \ldots \ldots$

14. Restriction Fragment Profile of Killer Whale MtDNA Cleaved With the Enzyme Saug6 I $\ldots \ldots \ldots \ldots \ldots \ldots \ldots 62$

15. Restriction Fragment Profile of Killer Whale MtDNA Cleaved With the Enzyme Alu I $\ldots \ldots \ldots \ldots \ldots \ldots \ldots \ldots 6, \ldots \ldots$

16. Hind III Restriction Patterns of Killer Whale AT8 obtained Due to Alteration of Reaction Conditions ..........66 66

17. Restriction Map of the $16.6 \mathrm{~kb}$ Killer Whale MtDNA Genome $\ldots \ldots \ldots \ldots \ldots \ldots 68$ 


\section{INTRODUCTION}

Analysis of mitochondrial DNA (mtDNA) polymorphism is being used extensively to examine the evolution and population structure of many organisms. The present study was undertaken to examine the mtDNA genome of killer whales in an effort to gain further information regarding killer whale population structure. Although genetic studies of wild killer whale populations have not yet been possible, captive killer whales originating from the North Atlantic and the North Pacific oceans were available for examination. Restriction fragment pattern variation in the mtDNA genome of killer whales was utilized to determine the level of genetic differentiation between killer whales from various geographic regions and to determine whether mtDNA variation exists between communities and pods of killer whales from the same geographic location.

\section{KILLER WHALES}

\section{Distribution}

Killer whales, orcinus orca L, are marine mammals that can be found in all oceans of the world (Figure 1). They have been reported from the North and South polar seas to tropical waters and from open ocean to coastal environments, but are thought to be concentrated in the 


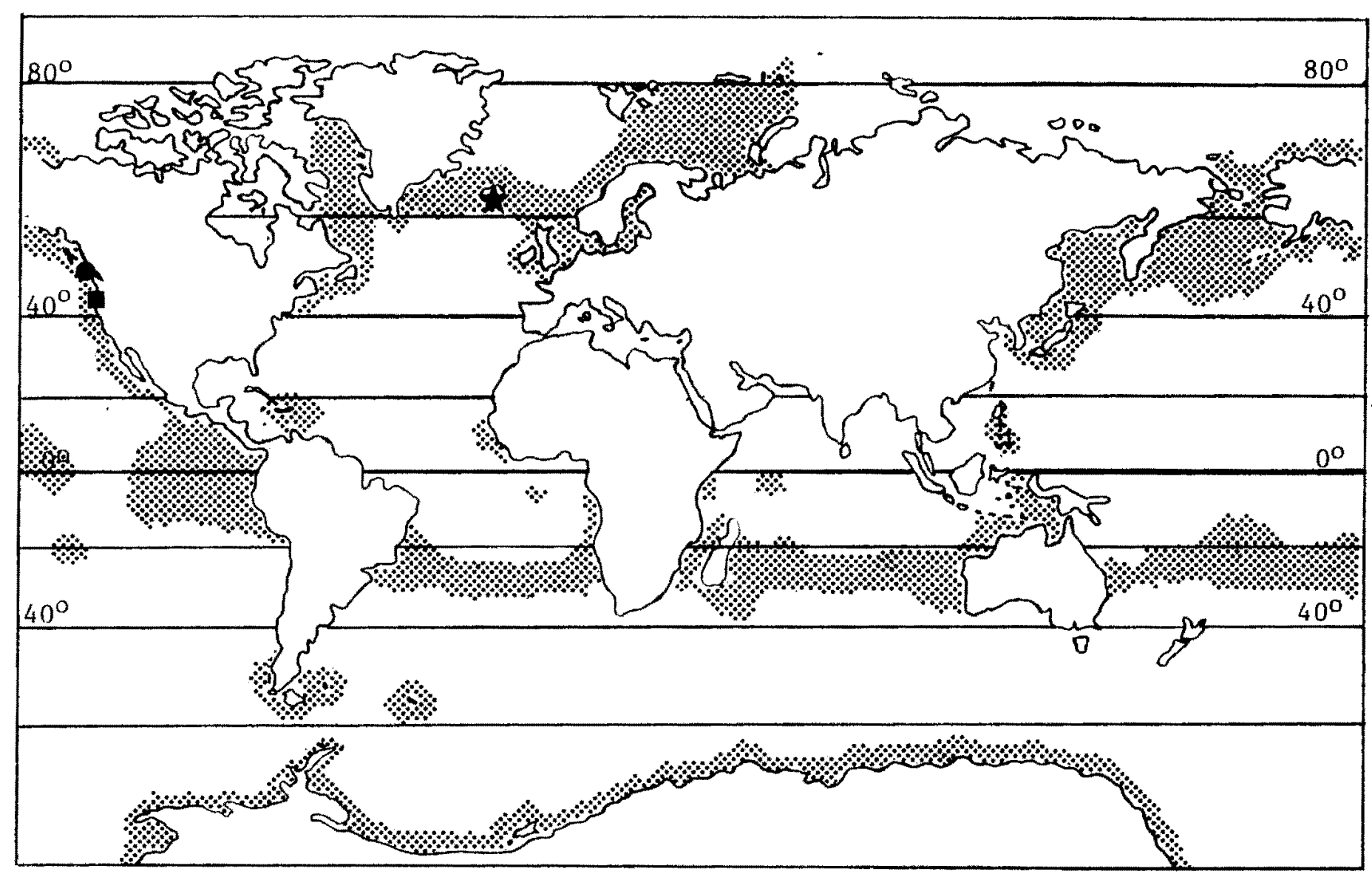

Figure 1. The worldwide distribution of killer whales. Adapted from Matkin and Leatherwood (1986).

$\lambda=$ capture site of killer whales from the Atlantic ocean.

- capture site of killer whales from the Pacific ocean.

- stranding site of killer whales from the Pacific ocean. 
colder waters of both hemispheres within a few hundred kilometres $(\mathrm{km})$ of the coast (see Mitchell 1975; Dahlheim et al. 1982; Perrin 1982; Matkin and Leatherwood 1986). The distribution of killer whales does not appear to be uniform, as the greatest number of sightings occur in coastal waters (Perrin 1982). It is not clear whether this distribution reflects actual differences in whale density among areas or if it is a product of variation in the level of observation between coastal waters and open ocean (Matkin and Leatherwood 1986).

\section{Systematics}

Until recently, killer whales were regarded as two geographically separate species. The name orcinus orca referred to the Atlantic animals, while orcinus rectipinna denoted the Pacific forms (Nishiwaki 1972; Matkin and Leatherwood 1986; Lockard 1986). Currently, they are considered to be monospecific, orcinus orca, with a number of potential races (Mitchell 1975). However, variation in the behavior and morphology of killer whales from different geographic locations has repeatedly led to proposals to once again divide these animals into more than one species. Mikhalev et al. (1981) proposed the name orcinus nanus to describe a form from the Antarctic which is smaller than killer whales from other regions and shows differences in diet, reproduction, physical appearance and behavior. 
Although this proposal was rejected by the International Whaling Commission (Perrin 1982), a new proposal has been submitted, based on similar criteria, to give killer whales from the Antarctic region the name orcinus glacialis (Bigg et al. 1987).

Geographic variation

Evans et al. (1982) noted geographic variation in the color patterns of killer whales from various locations. Antarctic animals have a distinct dorsal cape which is absent in killer whales from other regions. Differences in the shape and position of the post-ocular patch were observed between whales from McMurdo Sound, the Ross sea, the Antarctic peninsula and the Antarctic coast. Pods of killer whales inhabiting the British Columbia coast also exhibit variation in color pattern (Bigg et al. 1987).

\section{Killer whales of the Vancouver Island Region}

In 1973, an eight year study was begun to determine the abundance, movement patterns and population biology of killer whales around Vancuuver Island, British Columbia (Bigg 1982). This study was initiated in response to concern over the live-capture fishery of killer whales that existed in the vancouver Island area at the time (Bigg 1982). The results of this study provided new insight into the complex life history of the species. 
whales revealed that individual animals could be identified using features of the dorsal fin and saddle patch (the white markings along the back of the animal just behind the dorsal fin) which remain constant over time (Bigg 1982; Bigg et al. 1987). These features include variation between individuals in the size and shape of the dorsal fin and saddle patch as well as nicks, tears and scars on the dorsal fin, saddle patch and back (Figure 2). Adult males can be distinguished from females and juveniles by having a tall, erect dorsal fin of 3.5 to 5.5 feet in height (Bigg $1982)$.

killer whale Pods. The killer whales in the Vancouver Island area were found to travel in highly stable groups termed pods. Pods consist of the same individuals that travel together throughout the year. Individuals of pods originally observed in 1973 have been sighted together for 15 years, and some whales are known to have remained associated with one another for at least 20 years (Bigg et al. 1987).

Pod Communities. Killer whale pods in the Pacific Northwest appear to be part of a highly structured population. As of 1987, forty-nine pods had been recorded, with a total of 332 individuals (Bigg et al. 1987). Based on photoidentification studies of movement, pod association patterns, feeding behavior, physical appearance of the dorsal fin, location of the saddle patch and vocalizations, 

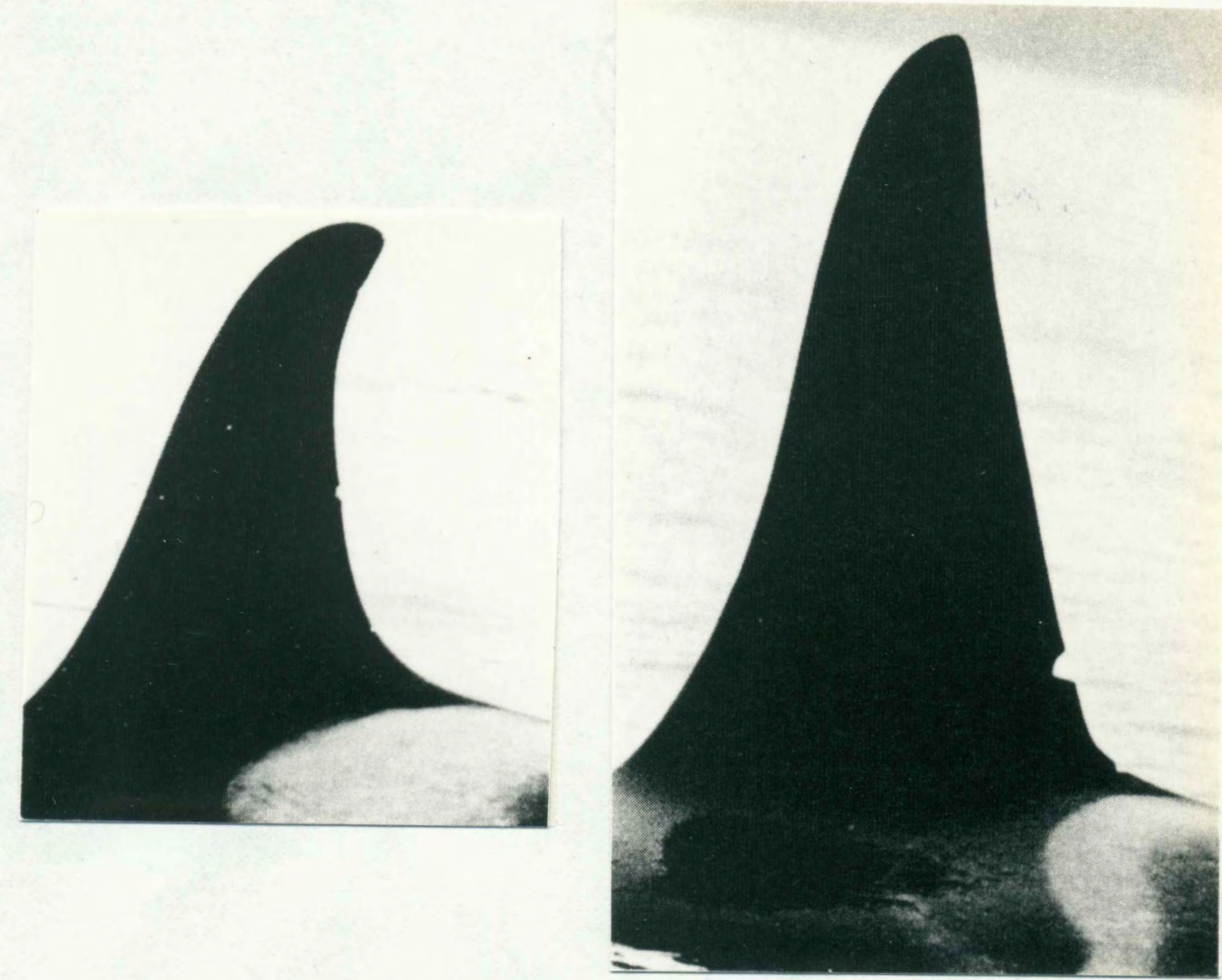

Figure 2. Identification photographs of two killer whales from the Vancouver Island region. Note the variation in size and shape of the dorsal fin and saddle patch between an adult female (on the left) and an adult male (on the right). The nicks in the dorsal fin are also used in identification of individuals. 
the pods have been divided into three different association groups or communities. The three communities are considered to be socially and reproductively isolated, since pods from the three different communities have never been observed in association with one another, although pods within each community do associate with each other. The northern resident community is composed of 16 pods containing approximately 170 individuals; the southern resident community has three pods of around 80 individuals; and, the transient community contains close to 30 pods consisting of around 80 individuals (Bigg 1982; Ford and Fisher 1982; Bigg et al. 1987).

Resident pods of killer whales are frequently seen around Vancouver Island and Puget sound from May to October and a few of the pods are occasionally present all year. Transient pods are present in the region throughout the year in about the same numbers, but are infrequently seen (Bigg 1982). This has led to an apparent contradiction of terminology since the transient pods appear to be year-round residents of the region while many of the resident pods leave the area during the winter months. In spite of the contradiction, the terminology originally given by Bigg (1982) is currently used by most biologists, and therefore will be utilized in this paper.

Resident pods of killer whales have been divided into two communities which are separated by a distinct boundary 
located in the waters between the mainland of British Columbia and vancouver Island at the mid-point of vancouver Island (Figure 3; Bigg 1982). This boundary appears to be strictly adhered to such that killer whales from both resident communities have not been observed to cross the boundary. Killer whales from the transient community are not affected by this boundary and will freely cross it.

Pod Movement Patterns. The range of resident pod movement has been estimated to be approximately $800 \mathrm{~km}$ along the coastline (Bigg et al. 1987). Northern resident community pods are reported to travel from the midVancouver Island boundary northward to the southeastern tip of Alaska. The southern community travels from the southern border of the northern community through puget Sound, around southern vancouver Island and down the coast of Washington State to Grays Harbor. Killer whale pods of the transient community travel within a coastal area of approximately $1450 \mathrm{~km}$ (Bigg et al. 1987), which includes the ranges of both of the resident communities and up to the Queen Charlotte Islands. It is not known how far offshore any of the three communities travel when they leave the vancouver Island region.

Both northern and southern resident community pods of killer whales tend to travel from headland to headland along the coast in a predictable manner. Transient pods travel unpredictably along the shoreline and will often 


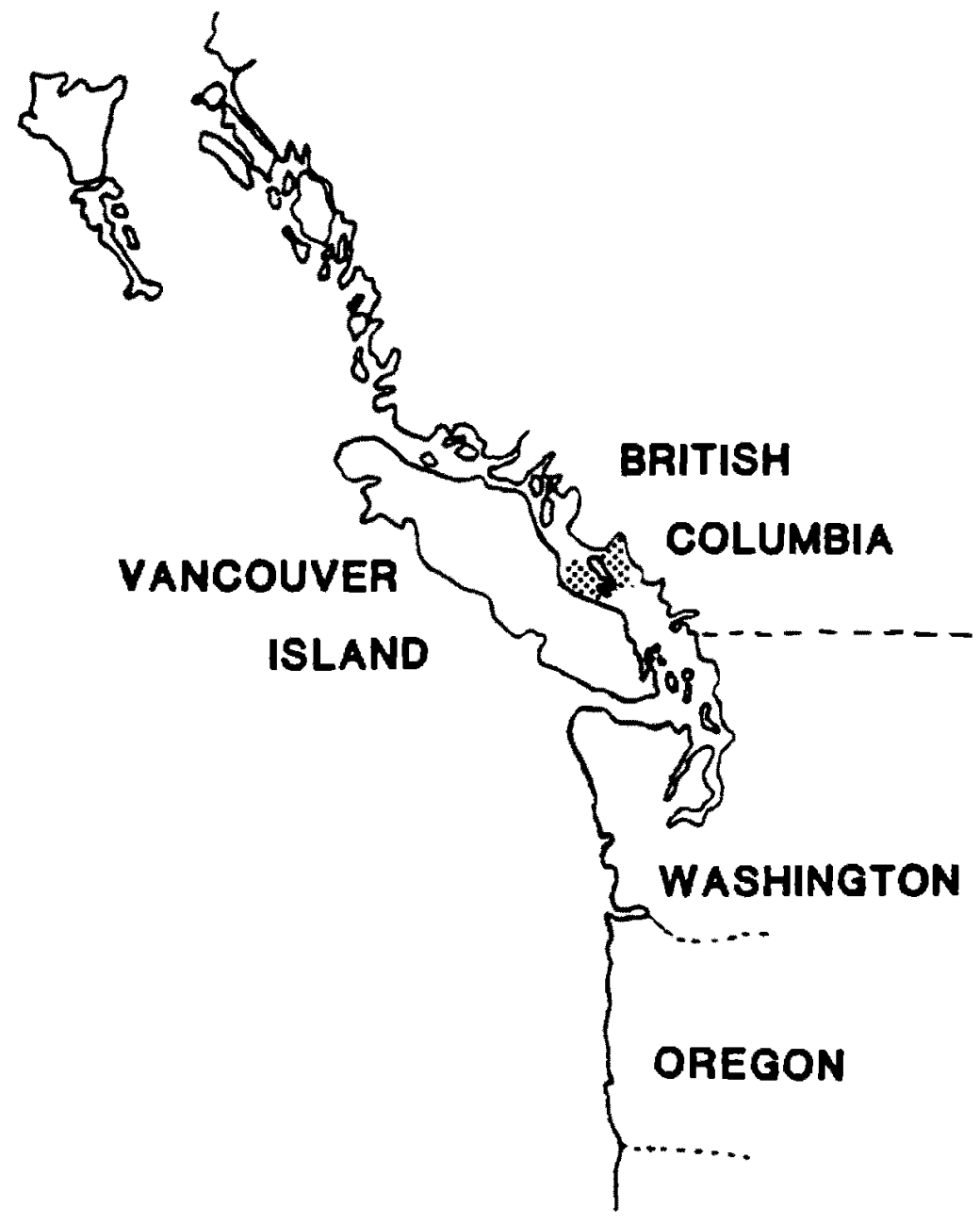

Figure 3. Map of Vancouver Island region. The boundary between northern and southern resident communities is shown (\$) . Adapted from Bigg and Wolman (1975). 
change direction or dive time abruptly, sometimes remaining at one feeding reef for several hours (Bigg 1982).

\section{Pod structure. Killer whale pods range in size}

between two to fifty individuals (Bigg 1982). Solitary individuals, both male and female, have also been sighted. Pods generally consist of adult males and females, juveniles and occasionally a new calf; however, several pods have been identified that lack adult males or are composed mainly of adult males. Within the vancouver Island region, most of the resident community pods contain five to fifty individuals (Bigg 1982). Pod structure is generally a mixture of males and females from various age classes. The transient pods are usually much smaller in size than resident pods, consisting of one to seven individuals (Bigg et al. 1987). Transient pods of killer whales often do not exhibit as wide a range of variation in age class or sex ratio as is seen in the resident pods.

Pods are believed to consist of maternally related individuals. Offspring have been observed to remain associated with their mothers well into maturity (Bigg 1982; Heimlich-Boran 1986). Mother/offspring relationships form stable subgroupings within the pods and young animals generally travel quite close to their mothers during the first years of life (Heimlich-Boran 1986).

Pods of killer whales within a community are occasionally observed to join together to form large 
aggregations that remain together for a few days to a few weeks (Bigg 1982). When the aggregation splits up, each pod reforms according to its original structure. Pods themselves generally do not split up for more than a few hours or a few days.

Diet. The major source of food for resident pods appears to be salmon and other fishes, while transients usually feed on marine mammals (Balcomb et al. 1980). There have been a few instances, however, of resident pod members feeding on marine mammals, so that this food source cannot be excluded from the diet of the resident pod animals (Balcomb et al. 1980). It has been suggested that the different feeding strategies between resident and transient pods have developed in order to divide the food resources in the region. This partitioning of food resources may have encouraged the development of the differences seen between the three communities in behavior, pod size and movement patterns (Bigg 1982).

Vocalizations. Ford and Fisher (1982; 1983) examined the vocalizations of killer whales in the Pacific Northwest and found that they emit discrete pulsed calls that can be easily distinguished acoustically and spectrographically. Each pod emits a limited number of discrete call types and each individual within the pod produces most, if not all, of these specific calls. The different pods identified by Bigg (1982) can be recognized through the vocalizations 
they produce. Certain calls are shared by many of the pods within a community, but there are also calls which are distinctive to a specific pod. Pods which share call types are generally those which frequently join together and travel as one unit. Call types are not shared between communities and each of the three communities in the region has its own specific repertoire of calls that differentiates the pods of one community from those of another.

Vocalization patterns of the transient community differ considerably from those of the resident communities. Transient pods are less vocal and are usually silent during periods of activity, whereas the resident pods exhibit the greatest amount of vocalization when active. Most pods of killer whales from other geographic regions will also remain silent while active, such as during attacks on marine mammals (Ljungblad and Moore 1983).

The dialects of the different pods are thought to aid in identifying social groups and group strategy during feeding as well as to maintain pod cohesion (Ford and Fisher 1983). The calls produced by resident pods during periods of activity are believed to coordinate the pod in searching for and capturing schools of fish (Hoelzel and Osborne 1986). Since the whales feed cooperatively on schools of fish, pod size can be fairly large.

Killer whales that feed on marine mammals are thought 
to remain silent because most prey species, if acoustically forewarned of the approach of a predator, would be able to escape well before the arrival of the predator (Ford and Fisher 1983). When searching for marine mammals, killer whales may use some other form of communication such as ultrasonic vocalizations which may be inaudible to the prey species (Valdez 1961; Ljungblad and Moore 1983).

New Pod Formation. It is believed that new pods form through the gradual splitting of established pods over a long period of time. New pod formation is thought to occur along maternal lineages as well (Bigg 1982). Individuals have not been observed to move out of one pod and into another on a permanent basis. Pods with similar call repertoires may have originated from the same ancestral group which split into smaller groups as it grew (Ford and Fisher 1983). As each new pod became more independent, it's acoustic repertoire changed as a result of behavioral or genetic isolation and drift.

\section{MITOCHONDRIAL DNA}

Mitochondria are organelles found within the cells of most eukaryotes (Cavalier-Smith 1987). They function to produce high energy ATP molecules through the process of respiration. Mitochondria contain an inner membrane infolded into numerous tubular projections called cristae. Proteins involved in respiration can be found within the 
inner membrane and in the internal matrix bounded by the membrane. DNA molecules are also located within the matrix. Several of the proteins involved in respiration are coded for by the mitochondrial DNA (mtDNA). other proteins are encoded by nuclear DNA, expressed via the cytoplasmic protein synthetic apparatus, and transported into the organelle.

The number of mitochondria and mtDNA molecules per cell varies depending on the species being examined. In mammals, there are approximately 500-800 mitochondria per cell, with each mitochondrion containing between one and ten mtDNA molecules (Lewin 1985). Mouse L cells contain $1100 \pm 250$ mtDNA molecules while human Hela cells have approximately 8800 mtDNA molecules (Bogenhagen and clayton 1974). Shmookler Reis and Goldstein (1983) reported values ranging from 2400-6000 mtDNA molecules per cell for human fibroblasts. The number of mtDNA molecules per cell was found to vary depending upon the age and the energy requirements of the cell.

\section{Genome Size, Structure and Content}

The mtDNA of animal cells is a closed, circular duplex molecule of approximately $10 \times 10^{6}$ daltons (Tzagaloff 1982). It consists of two strands which vary in their $G+T$ content such that the buoyant densities of the strands are different in alkaline cesium chloride gradients 
(Brown 1983). Due to this strand bias, one strand has been designated heavy (H-strand) and the other light (L-strand). The mtDNA molecule contains genes that code for tRNAs, rRNAs and mRNAs. There is also a short regulatory region that contains sites for the initiation of DNA replication and RNA transcription as well as sequences that are involved in the regulation of replication and gene expression (Figure 4).

Among mammals, the mtDNA genome has been completely sequenced for the cow (Bos taurus; Anderson et al. 1982), mouse (Mus musculus; Bibb et al. 1981) and human ( sapien; Anderson et al. 1981). Comparison of these sequences revealed that the mitochondrial genome has a highly compact gene arrangement (Brown 1983; 1985). Intergenic sequences are much reduced, as compared to nuclear DNA, or are completely absent. In several cases, adjacent genes overlap one another. There is also an absence of introns within structural genes. This reflects very economic use of the genetic material available within the mammalian mitochondrial genome.

All of the genes coding for RNA and proteins have been identified and located on the mammalian mtDNA genome. These include 22 tRNAs, the $12 \mathrm{~S}$ and $16 \mathrm{~S}$ rRNAs, cytochrome B, cytochrome oxidase subunits I, II and III, mitochondrial ATPase subunit 6 (Anderson et al. 1981), NADH dehydrogenase complex subunits 1-5 (Chomyn et al. 1985), 


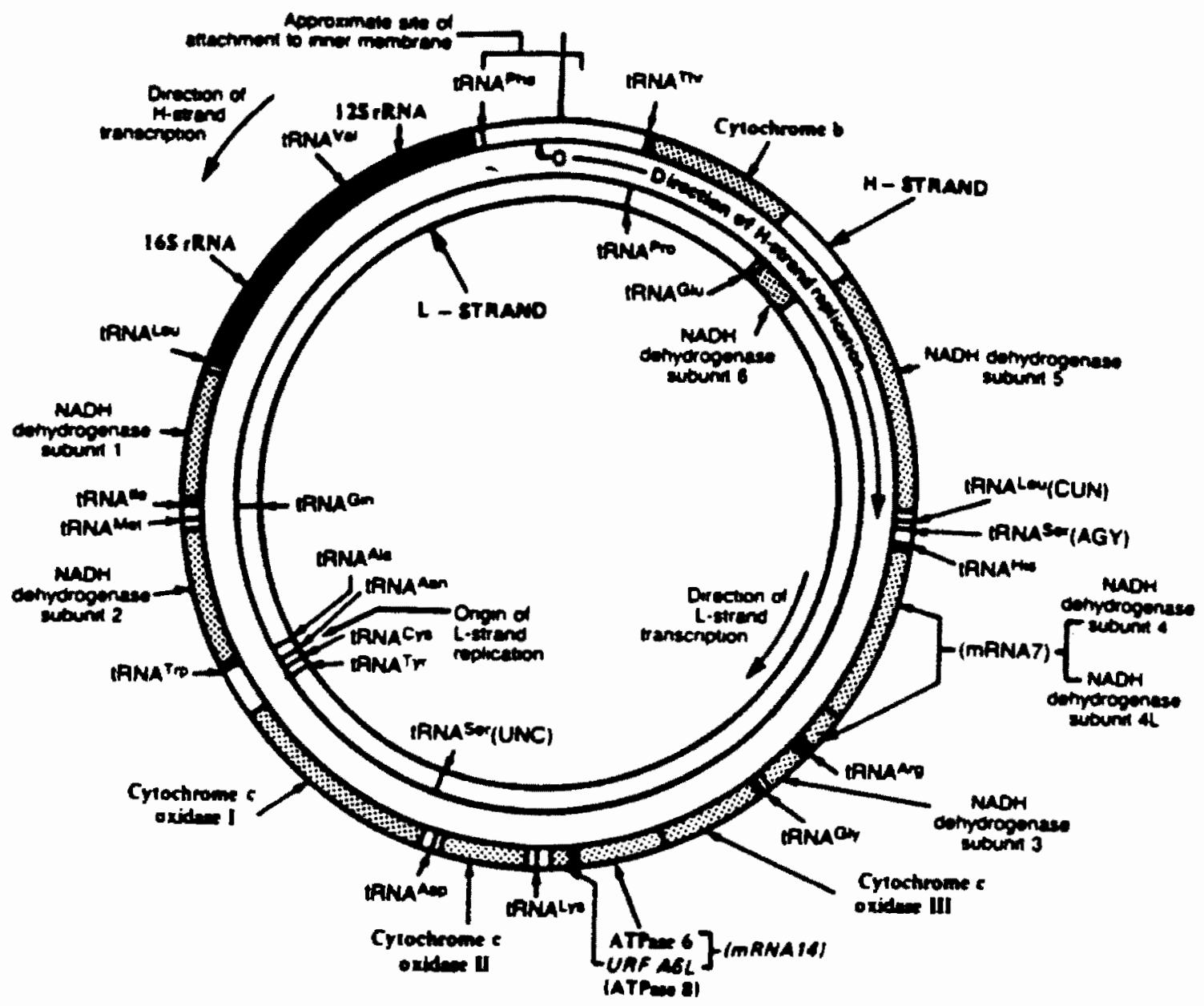

Figure 4. Genetic map of the human mtDNA molecule. From Mckusick (1987). 
NADH dehydrogenase complex subunit 6 (Chomyn et al. 1986) and mitochondrial ATPase subunit 8 (Mariottini et al. 1983). Gene arrangement along the genome has been highly conserved and is virtually identical among the mammals that have been examined (Anderson et al. 1982; Brown 1985), indicating that stability of gene order has been maintained since the evolutionary divergence of mammals.

Replication

Replication of mtDNA is continuous, asymmetrical and unidirectional. It is initiated independently on each of the two complementary strands, with each strand having a fixed origin of replication approximately 5000 base pairs (bp) apart (Brown 1985). Replication begins with H-strand synthesis at the origin located in the control region. It continues for approximately 500 to 700 bp, stopping at a discrete point along the H-strand (Clayton 1982). This short region of DNA is referred to as the displacement loop (D-loop) since the newly synthesized piece of DNA often displaces the H-strand, creating a three stranded structure. The majority of mtDNA molecules within a cell are of this form, referred to as D-mtDNA. When replication is reinitiated, it continues with H-strand synthesis past the D-loop region in a continuous and unidirectional manner (Clayton 1982). Replication of the L-strand is initiated only when H-strand synthesis has proceeded past, 
and exposed, the site of the origin of L-strand synthesis. Using the parental H-strand as a template, L-strand synthesis proceeds in the opposite direction. When Hstrand synthesis is completed, the daughter molecules are separated. L-strand synthesis is completed after separation of the daughter molecules.

The Displacement Loop

The D-loop spans the region between the Phe-tRNA and Pro-tRNA genes. It contains the promoters for $\mathrm{H}$ and $\mathrm{L}-$ strand transcription and the origin for H-strand replication (Clayton 1984). The D-loop can be divided into three domains: the left ( $L$ ) domain located at the $5^{\prime}$ end of the D-loop, the right (R) domain located at the $3^{\prime}$ end of the D-loop region and a central (C) domain. Both the $R$ and $L$ domains have a low $G$ content $(10-148)$ and are highly variable for both base sequence and length (saccone et al. 1987). They do, however, contain thermodynamically stable secondary structures. In the L domain, the stable structure forms a cloverleaf configuration and contains a conserved sequence block (CSB-1; Walberg and Clayton 1981) which is thought to be associated with the initiation of $\mathrm{H}-$ strand synthesis (Brown et al. 1986). The R domain contains a similar sequence block, TAS, which is associated with the termination of H-strand synthesis (Doda et al. 1981) and also has well preserved secondary structures 
whose stable configuration may be cloverleaf or multiple stems and loops (Hixson et al. 1986). Between the $R$ and $L$ domains is a region of approximately 200 bp which is highly conserved in mammals and has a higher $G$ content than the other domains (20\%) (Saccone et al. 1987). This C domain has been found to contain several open reading frames of variable length. Saccone et al. (1987) suggest that the preserved cloverleaf structures within the D-loop region interact with other RNA molecules and/or protein factors to regulate the processes of replication and transcription.

\section{Genetic Code}

The genetic code of animal mtDNA differs slightly

from that found in eukaryotic nuclear and prokaryotic systems. Translation of the mitochondrial code is carried out using only 22 tRNAs, rather than the 32 used in the "universal" code. All of these tRNA molecules are coded for by the mitochondrial genome (Barrell et al. 1979). Differences between the "universal" code and the mitochondrial code are as follows: UGA codes for tryptophan rather than being a stop codon; AUA codes for methionine rather than isoleucine; in addition to the AUG sequence, AUA, AUU and AUC can function as initiator codons; and, AGA and AGG function as stop codons rather than coding for arginine (Barrell et al. 1980).

The decrease in the number of tRNAs required for 
translation of the mitochondrial code is believed to be due to a different decoding mechanism in the mitochondrial genetic system. In the genetic code boxes where four codons code for one amino acid (a codon family), a "two out of three" base interaction between codon and anticodon is suggested. One tRNA with an unmodified $U$ in the first position of the anticodon can pair with all four bases in the third (wobble) position of the codons in each family box (Barrell et al. 1980). In the non-family boxes (those in which two amino acids are coded for), the two codons ending in pyrimidines are recognized by tRNAs with an unmodified $U$ such as described above. The other two codons, which end in purines, are recognized by tRNAs which have a modified $U$ in the first anticodon position.

Modification of the $U$ would prevent misreading of codons in the non-family boxes (Barrell et al. 1980). This translational mechanism decreases the number of tRNAs required from 32 to 24 . The mitochondrial genetic system has been further simplified by the absence of arginine codons in mitochondrial genes, and therefore the loss of a tRNA with the corresponding anticodon (Anderson et al. 1981). Furthermore, only one Met-tRNA gene has been located in mammalian mtDNA. Secondary modification of the primary transcript produces both methionine-tRNA and Nformyl-methionine-tRNA (Attardi 1985). Therefore, only 22 tRNAs are required for protein synthesis within the 
mitochondrion. Jukes (1983) has suggested that the mitochondrial genetic code may have been derived from the "universal" code by a retrogressive simplification in which many anticodons were deleted such that only the bare minimum of anticodons required for the 20 amino acids used in protein synthesis are present.

\section{Transfer RNA}

Mitochondrial tRNA molecules are generally smaller than nuclear coded tRNAs, ranging in size from 59 to 75 nucleotides in humans (Attardi 1985). All contain the 3' terminal-CCA sequence, although it is not encoded by the mtDNA tRNA genes. It is believed that this sequence is added post-transcriptionally (Clayton 1984). The structure of mitochondrial tRNAs also varies from that of their nuclear counterparts. Nuclear encoded tRNA molecules exhibit a number of invariant features such as length of stems and loops and the presence of specific nucleotide sequences at specific positions (Gauss and sprinzl

$1984 a, b)$. Many of these features are variable or lacking in mitochondrial tRNAs. The "DHU" and "TYC" stems and loops exhibit variation in length, the most extreme example of which is the ser-tRNA which completely lacks the "DHU" stem and loop (de Bruijn et al. 1980). Most mitochondrial tRNAs lack the constant $G$ at position 15, which in nuclear tRNAs pairs with a constant pyrimidine at position 48 to 
provide tertiary stability (Attardi 1985). Many of the sequences in nuclear tRNAs that are involved in secondary structure formation are absent in most mitochondrial tRNAs (clayton 1984). It has also been found that the level and pattern of methylation is different in mitochondrial tRNAs (Attardi 1985). Taken together, the alterations of mitochondrial tRNAs from the invariant nuclear tRNAs indicate that mitochondrial tRNA molecules have a lower secondary and tertiary structure stability, suggesting greater evolutionary flexibility in mitochondrially encoded tRNAs (Attardi 1985).

\section{$\underline{\text { Size Variation }}$}

There is very little variation in size between mammalian mtDNAs. All genomes that have been examined fall within the narrow range of $16,500 \pm 200 \mathrm{bp}$, except for the domestic rabbit (Oryctolagus cuniculus) which is $17,300 \mathrm{bp}$ (Brown 1983). The greatest amount of size variation appears to have occurred within the control region (D-loop) of mtDNA. As described earlier, the D-loop contains the origin of H-strand replication and the initiation sites for transcription. These regions themselves are highly conserved, and the majority of size variation occurs in the sequences surrounding these sites. The important feature of these sites appears to be that the secondary structure of stems and loops be maintained to allow for efficient 
protein-DNA interactions (saccone et al. 1987). Primary sequences do not appear to be as important as long as the integrity of secondary structures remains.

The remainder of the mitochondrial genome exhibits only microvariation in size (Brown 1985). Most addition and deletion events are small alterations of one to four base pairs. These changes have been seen mostly in tRNA and rRNA genes, and are only rarely found in the protein coding genes (Brown 1983). It is likely that these regions of the mitochondrial genome have remained highly conserved due to function related constraints during mammalian evolution. Such constraints would prevent many mutations from remaining within the genome through inherent repair systems, or by rendering the genetic products lethal to the organism. It therefore appears that the size of genes which code for functional protein products are under strong selective pressure to remain stable.

Nucleotide Sequence Evolution

The majority of the alterations that are seen between mammalian mitochondrial genomes are due to changes in nucleotide sequence (Brown 1983). Anderson et al. (1982) found that a high proportion of the observed codon changes between human and bovine mtDNA sequences were silent substitutions. The alterations were mainly in the third position of the codon such that the amino acids produced 
were identical and did not cause any change in the corresponding protein. For example, the gene coding for cytochrome oxidase subunit III showed 78.98 sequence homology, but $87.0 \%$ amino acid conservation. Within humans, most of the mutations outside of the D-loop region have been found to be due to single base pair alterations (Aquadro and Greenberg 1983; Brown et al. 1982; Whittam et al. 1986). Similar results were noted by Brown and simpson (1982) for two species of rat. Upon comparison of the sequences of the species, $94.4 \%$ of the nucleotide substitutions were found to be silent.

single base pair mutations in mtDNA appear to be biased towards transitions ( $A<-->G$ and $T<-->C$ ) over transversions (A or $G<-->C$ or $T$ ) (Anderson et al. 1982; Brown and simpson 1982). The bias appears to decrease as estimated divergence time between species increases. It has been suggested that an equilibrium between the number of transitions over transversions $(\mathrm{S} / \mathrm{V}=0.5)$ is attained only after considerable time has elapsed since species divergence.

It is not clear why this transitional bias exists. Aquadro and Greenberg (1983) suggest that much of the bias is probably due to the mutational process rather than selection against transversions, since models of mutation predict that transitions will occur at a higher frequency due to the chemical composition of the bases. Certain DNA 
alterations, such as the deamination of 5-methylcytosine to thymine, will occur frequently on single stranded DNA (Lewin 1985). Since the H-strand of mtDNA is unpaired during much of the replication cycle, transitions of this type could occur on the unpaired H-strand (Brown and Simpson 1982). There have been no reports of a system within mitochondria that would recognize and repair such alterations as they occurred (Clayton 1982).

Recombination

MtDNA does not appear to undergo recombination except perhaps in the D-loop (Olivo et al. 1983). Recombination is the physical exchange of homologous regions of DNA. It is a process which creates new genetic combinations in diploid genomes when there are contributions from both parents. These new combinations can, through the action of natural selection, be an important force in evolutionary change. Since mtDNA does not undergo recombination, this source of variation and selection is not available to the mtDNA molecule. Therefore, the only changes that can occur within the mtDNA genome are through mutational events.

\section{Rapid Rate of Mitochondrial DNA Evolution}

MtDNA has been shown to exhibit a high rate of mutation. Restriction endonuclease cleavage site mapping and thermostability experiments of the mtDNA of four primate species revealed nucleotide sequence divergence 
between species pairs was much higher in mtDNA than in single copy nuclear DNA (Brown et al. 1979). It was concluded that mtDNA evolves five to ten times faster than single copy nuclear DNA. A rate of $5 \times 10^{-9}$ to $10 \times 10^{-9}$ base substitutions per nucleotide position per year was given for mammalian mtDNA. Many other studies have confirmed the high evolutionary rate of mtDNA (Dawid 1972; Brown et al. 1982), although this rate is only applicable to closely related species. For species that have been separated for a longer period of evolutionary time the rate of mtDNA evolution appears to be slower (Anderson et al. 1982). As divergence time between species increases, the chance for multiple base substitutions to occur at the same nucleotide position increases. Multiple substitutions would mask the actual amount of change that has occurred between the species, thus making it appear that the rate of change is slower than it actually is (Brown et al. 1982).

The high evolutionary rate of mtDNA appears to be due to a combination of the features of the mitochondrial system that have already been discussed. Many mutations could be set into the mtDNA molecule due to the lowered fidelity of mtDNA polymerase, an enzyme which is reported to incorporate mispaired bases approximately five times more frequently than nuclear DNA polymerases during replication (Kunkel and Loeb 1981). The absence of recombination and the apparent lack of a mtDNA repair 
system would prevent the removal of many mutations (Clayton $1982)$.

The simplified genetic code allows for a high proportion of silent nucleotide substitutions to occur in the third position of the codons (Anderson et al. 1982). These mutations are neutral with regard to the amino acids and proteins produced, and therefore would remain unaltered in the mtDNA and be passed on to the offspring. The majority of mtDNA mutations are due to silent nucleotide substitutions of this type.

While the mtDNA molecule as a whole has a relatively rapid rate of evolution, the rate at which amino acid altering mutations occur in mtDNA is comparable to that of nuclear DNA (Brown and Simpson 1982). When only the mutations that alter the amino acid composition of proteins are examined, the proteins that are produced by mtDNA evolve at a rate similar to those produced by nuclear DNA. Thus the difference in rate between nuclear DNA and mtDNA evolution can be partially attributed to the ability of mtDNA to accumulate a large number of silent nucleotide substitutions.

Many of the structural changes that occur in the tRNA molecules would also tend to be neutral due to the relaxed constraints of the mitochondrial translational apparatus (Cann et al. 1984). The regulatory function of the D-loop region appears to be dependent upon the secondary structure 
of each domain rather than primary base sequence (Saccone et al. 1987). Therefore, nucleotide alterations can occur and be maintained within the mtDNA as long as the secondary structure of the nucleic acids remains unaffected. The frequency of nucleotide changes in the D-loop region may be enhanced due to the fact that the H-strand is unpaired during most of the mtDNA replication cycle (clayton 1982).

\section{Mitochondrial DNA Inheritance}

MtDNA has been shown to exhibit a pattern of maternal inheritance. In humans, the mtDNA of several unrelated families were examined for nucleotide sequence polymorphisms (Giles et al. 1980). In each of the families where distinctly different restriction endonuclease cleavage patterns were detectable between the parents, all offspring exhibited the maternal cleavage pattern. The results were not consistent with $\mathrm{x}$-linked inheritance, autosomal dominance or recessiveness, or codominance patterns but strongly supported the theory of maternal inheritance of mtDNA.

Although most of the mtDNA is transmitted to the offspring through the egg cytoplasm, sperm carry a small amount of mitochondria. Therefore, low levels of paternal mtDNA contribution could conceivably occur. Lansman et al. (1983) tested this possibility by examining two hybridized strains of tobacco budworm (Heliothis) which had been 
backcrossed for 91 generations. It was believed that if males had contributed even small amounts of mtDNA to the progeny, repeated backcrossing would enrich the total paternal mtDNA input to detectable levels. All of the mtDNA observed was of the original maternal type. These results permitted setting an upper limit of paternal input to one molecule per 25,000 per generation.

The Use of Mitochondrial DNA in Population Genetics

Examination of the mtDNA molecule has become a useful tool in evolutionary biology because it is a small, isolated molecule of high copy number; it has a high rate of evolution; it has a unisexual mode of transmission and it is highly conserved in size and gene arrangement within mammals.

Most studies involving mtDNA analysis are population surveys that utilize intraspecific variation of mtDNA to construct matriarchal phylogenies (Avise et al. 1979; Cann et al. 1987). The evolutionary pathways of closely related species have also been examined (Brown et al. 1982; Thomas et al. 1986; Hixson and Brown 1986). These studies generally follow a similar methodology which has been reviewed by Lansman et al. (1981). MtDNA is typically isolated from the tissues of individual organisms and cleaved with a variety of type II restriction endonucleases. These are enzymes that recognize and cleave 
DNA at specific oligonucleotide sequences (Maniatis et al. 1982). The DNA fragments are then separated by molecular weight by gel electrophoresis and the fragments are visualized using a variety of methods which include ethidium bromide staining, end-labelling of fragments with radioactive nucleotides and southern transfer followed by hybridization with a DNA probe (Maniatis et al. 1982). The number and size of each fragment produced by restriction enzyme digestion are then scored for each individual and compared to other individuals that have been similarly examined.

The results of population surveys and evolutionary studies generally reveal restriction fragment length polymorphisms between the mtDNA of individuals, populations or species. These polymorphisms allow one to recognize mtDNA variation between the groups. An index of the genetic similarity between the mtDNA of different organisms is calculated as the proportion of fragments shared in their digestion profiles. Often the positions of restriction sites are mapped relative to one another to illustrate the sites on the mtDNA genome where variation between organisms occurs. Many statistical procedures have been developed which convert the raw fragment or site data to quantitative estimates of nucleotide sequence divergence between mtDNA types (Nei and Li 1979; Nei and Tajima 1983). Phylogenetic relationships and estimates of divergence time 
among closely related organisms can also be inferred from the raw fragment data (Li 1986).

Most restriction endonucleases used to cleave mtDNA have been shown to have an extremely non-random pattern of restriction (Adams and Rothman 1982; Aquadro and Greenberg 1983). The reason for this may be that the restriction sites themselves, or sequences that include the recognition sites are under some form of selection. An alternate hypothesis is that the non-random distribution of recognition sequences may reflect non-random codon usage by the mitochondrial genome. The consequence of this is that estimates of phylogenetic relationships using restriction site data will be biased. The extent of this bias is dependent on the enzymes that are used and the distribution of restriction sites on the mtDNA genome that is being examined.

\section{GOALS OF THE STUDY}

Genetic studies of killer whales in the wild have not been possible to date. However, blood and tissue samples of captive and stranded killer whales originating from the North Atlantic and from the resident and transient communities of the North Pacific were available for study. An analysis of killer whale mtDNA restriction fragment patterns was undertaken to address the following questions: 
1) What is the level of mtDNA differentiation between killer whales from different geographic locations?

2) Does mtDNA variation exist between communities or pods of killer whales from the same geographic location?

3) Can mtDNA restriction fragment polymorphisms be used to distinguish between killer whales from different pods, communities or populations? 
MATERIALS AND METHODS

\section{STUDY ANIMALS}

Twenty-one killer whales from zoological collections in Canada and the United States were available for examination (Table I). Ten of the whales were of Atlantic origin, having been captured along the southeastern coast of Iceland during the annual october to December herring runs (see Figure 1). One whale (CB1) was a captive-born cross between an Atlantic killer whale female (AT5) and a Pacific killer whale male (not part of this study). Another whale ( $C B 2$ ) was a captive-born cross between an Atlantic killer whale female (AT7) and a Pacific killer whale male (PRI; D. Duffield, pers. comm.). Nine whales were of Pacific origin (see Figure 1). Seven of these were captured at various sites around vancouver Island, British Columbia during the live-capture fishery that existed in Washington and British Columbia between 1962 and 1973 (Bigg and Wolman 1975). The two additional Pacific killer whales used in the study were calves which stranded along the oregon coast. See Table I and Figure 5 for a listing and illustration of the capture and stranding sites of the Pacific origin killer whales.

It was possible to determine the original pod 
TABLE I

KILLER WHALES USED IN THIS STUDY LISTED BY CAPTURE DATE AND SITE, SEX AND TISSUE TYPE USED TO OBTAIN MITOCHONDRIAL DNA SAMPLES

\begin{tabular}{|c|c|c|c|c|}
\hline $\begin{array}{l}\text { I DENT I TY } \\
\text { NUMBER }\end{array}$ & $\begin{array}{c}\text { DATE } \\
\text { CAPTURED }\end{array}$ & $\begin{array}{l}\text { CAPTURE } \\
\text { SITE }\end{array}$ & SEX & $\begin{array}{c}\text { TISSUE } \\
\text { OBTAINED }\end{array}$ \\
\hline AT1 & 1977 & Icelandic coast & $\mathbf{F}$ & BLOOD \\
\hline AT2 & 1977 & Icelandic coast & $\mathbf{F}$ & BLOOD \\
\hline AT3 & 1977 & Icelandic coast & $\mathbf{F}$ & BLOOD \\
\hline AT 4 & 1978 & Icelandic coast & M & BLOOD \\
\hline AT5 & 1978 & Icelandic Coast & $\mathbf{F}$ & BLOOD \\
\hline AT6 & 1980 & Icelandic Coast & M & BLOOD \\
\hline AT7 & 1980 & Icelandic Coast & $\mathbf{F}$ & BLOOD \\
\hline AT8 & 1982 & Icelandic coast & $\mathbf{F}$ & BLOOD \\
\hline AT9 & 1982 & Icelandic Coast & $\mathbf{F}$ & BLOOD \\
\hline AT10 & 1984 & Icelandic Coast & M & BLOOD \\
\hline$\star$ CB 1 & 1985 & --ー-ー-ー-ー & $\mathbf{F}$ & BLOOD \\
\hline * CB 2 & 1988 & -・ー-ーーーー & $\mathbf{F}$ & HEART/LIVER \\
\hline PR1 & 1968 & Pender Harbour, B.C. & M & BLOOD \\
\hline PR2 & 1968 & Pender Harbour, B.C. & $\mathbf{F}$ & BLOOD \\
\hline PR3 & 1969 & Pender Harbour, B.C. & $\mathbf{F}$ & BLOOD \\
\hline PR4 & 1969 & Pender Harbour, B.C. & M & BLOOD/HEART \\
\hline PR 5 & 1970 & Penn Cove, WA & $\mathbf{F}$ & BLOOD \\
\hline T1 & 1970 & Pedder Bay, B.C. & $\mathbf{F}$ & BLOOD \\
\hline $\mathrm{T} 2$ & 1975 & Pedder Bay, B.C. & M & BLOOD \\
\hline$+\mathrm{S} 1$ & 1987 & Astoria, oR & M & HEART/LIVER \\
\hline$+\mathrm{S} 2$ & 1988 & Newport, OR & $\mathbf{F}$ & HEART/LIVER \\
\hline
\end{tabular}

* = captive-born killer whales to Atlantic origin females. $+=$ stranded killer whales. 


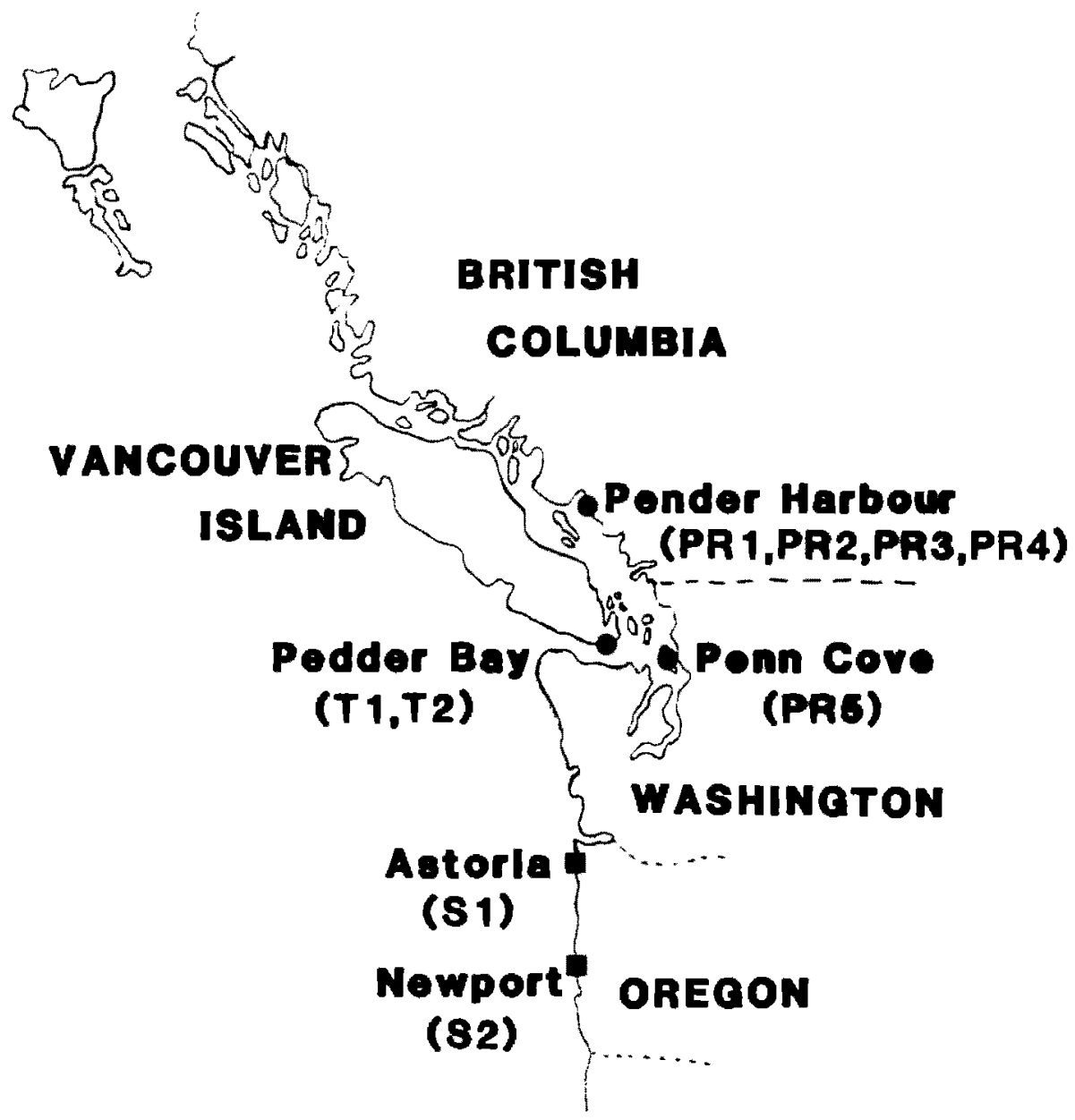

Figure 5. Location of live-capture ( $\bullet$ ) and stranding ( a) sites for Pacific killer whales. 
affiliations of the captive killer whales from the Pacific ocean. The identifications were performed by Bigg (1982) through examination of photographs taken during capture proceedings. Comparisons were made between animals in the photographs that were released and the present pod associations of those animals. Due to the long-term stability of killer whale pods (see Introduction), it is believed that the captured animals were affiliated with the pod of which they were a part during capture proceedings. Killer whales PR1, PR2, PR3 and PR4 are from pod $A 5$ of the northern resident community. The exact pod association of whale PR5 could not be determined, although it is known to have come from one of pods $J, K$ or $L$ of the southern resident community. The remaining two whales are from the transient community with $T 1$ originating from pod $Q$ and $T 2$ originating from pod $M$.

\section{SAMPLING AND EXTRACTION PROCEDURES}

Blood samples of the captive killer whales were obtained by fluke venipuncture using a plastic disposable syringe with an 18 or 20-gauge needle. Six to $15 \mathrm{ml}$ of blood was provided per animal and was placed in either heparinized or EDTA Vacutainer tubes. The whales were conditioned to present their tail flukes for sampling, and repeat samples were available on all animals with the exception of the one animal that died during the study 
period. The blood was transported on ice to the laboratory where it was immediately refrigerated. Total DNA, including nuclear and mtDNA, was extracted from the bloods within 2-7 days of drawing.

The DNA was extracted from white blood cells and platelets following the protocol given in Appendix A. A DNA yield of 126-308 $\mu \mathrm{g}$ was obtained in a concentration of $0.4-0.8 \mu \mathrm{g} / \mu 1$. Approximately $1.0 \%$ of the total DNA yield was mtDNA. This value was determined by isolating purified mtDNA from blood.

In addition to a total DNA extraction, purified mtDNA was extracted from the blood samples of two captive killer whales, $C B 1$ and $A T 3$. A modified version of the extraction procedure described by Wrischnik et al. (1987) was used. The protocol is given in Appendix B. The purified mtDNA obtained from this procedure was used to estimate the amount of mtDNA in the blood samples, and was also used to determine whether nuclear DNA contamination would affect the results. A mtDNA yield of approximately $3.0 \mu \mathrm{g}$ was obtained from $9.0 \mathrm{ml}$ of whole blood.

Post-mortem muscle and/or liver samples were available from the two stranded calves. The tissues were frozen at $-20^{\circ} \mathrm{C}$, and purified mtDNA was extracted from the frozen tissues using the method of Lansman et al. (1981). Five grams of tissue yielded approximately $50 \mu \mathrm{g}$ of mtDNA. 
One captive Pacific whale and one captive-born calf died during the study period. Cardiac and liver tissue were removed during routine post-mortem and immediately transported on ice to the laboratory. MtDNA extraction of the tissue was performed immediately upon arrival at the laboratory.

since a mtDNA probe was used to identify the mtDNA fragments from the killer whales, it was not necessary to isolate highly purified mtDNA from tissue using the procedure of Lansman et al. (1981). A less expensive and less time-consuming method, which isolates partially purified mtDNA from tissue, was utilized to extract mtDNA from the fresh muscle tissue of the two captive animals that died. The protocol is an adaptation of the method of Jones et al. (1988) and is given in Appendix C.

\section{MITOCHONDRIAL DNA PROBE}

Preparation of Mitochondrial DNA Probe

A mtDNA probe was used to visualize the killer whale mitochondrial genome. The probe was kindly provided by s. Southern of the University of California, San Diego. It consists of the whole mtDNA genome of Commerson's dolphin (Cephalorhynchyus commersonii) which has been cloned in five separate fragments into the plasmid, pACYC 184 (Figure 6; Southern et al. 1988). The plasmids were provided lyophilized. All five portions of the mtDNA 


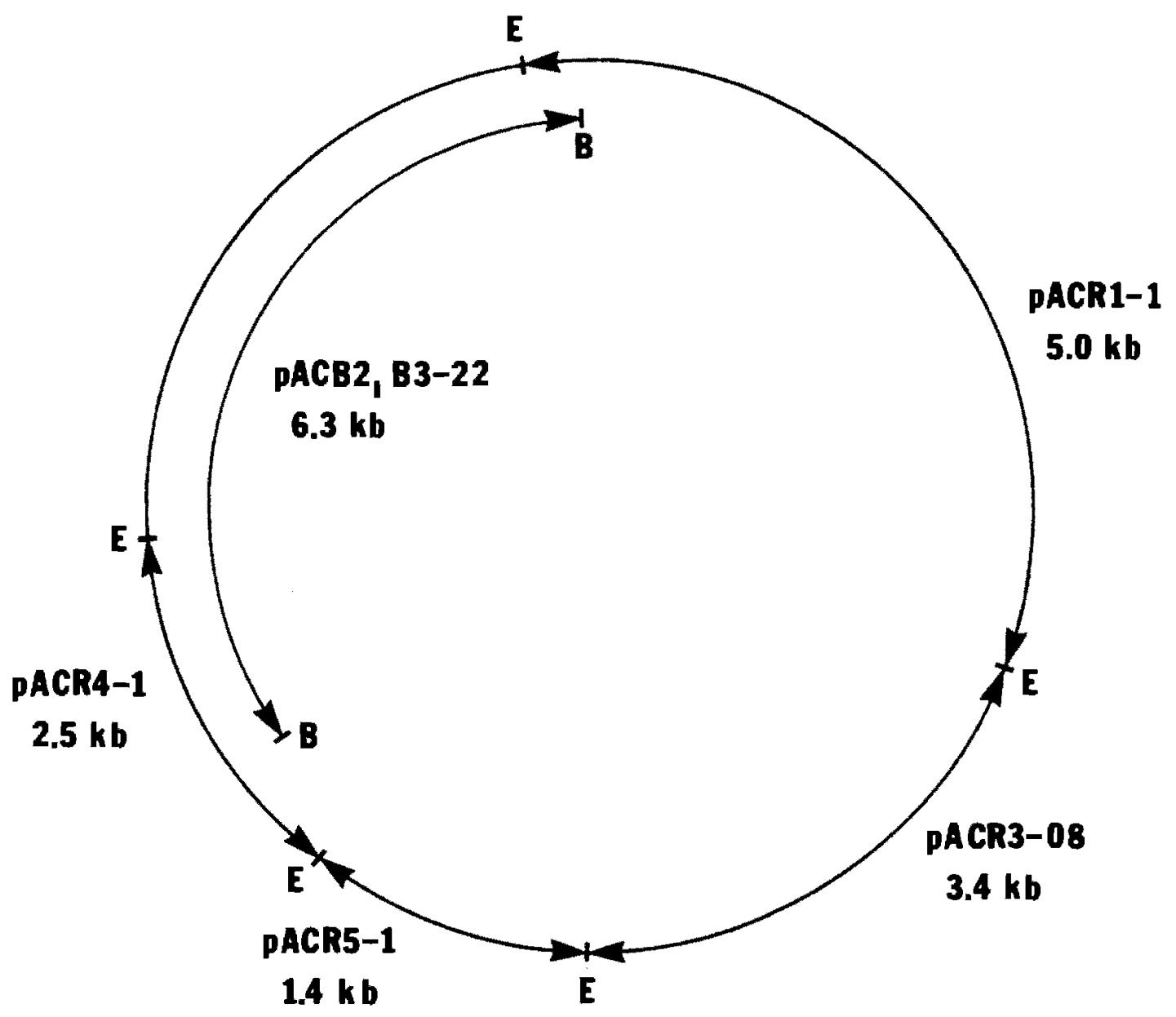

Figure 6. Restriction map of the cloned sites on the mtDNA molecule of Cephalorhynchus commersonii, Commerson's dolphin. E = EcoR I sites; $\bar{B}=$ BamH I sites. Adapted from Southern et al. (1988). 
genome were introduced into Escherichia coli HB101 cells by using a modification of the calcium chloride procedure of Hanahan (1983) (Appendix D). E. Coli colonies that grew on the appropriate antibiotic medium were then screened for the presence of recombinant plasmids using the plasmid mini-preparation method of Riggs and McLachlan (1986). Five successfully transformed colonies, each containing one of the mtDNA fragments of interest, were grown to a high density and the plasmids isolated using a modification of the alkaline lysis-cesium chloride density gradient procedure described by Maniatis et al. (1982) (Appendix E). The Commerson's dolphin mtDNA genome was used as a hybridization probe in order to visualize the killer whale mtDNA genome. For most of the experiments, the whole dolphin mtDNA genome was utilized as a probe. When it was necessary to determine the location of killer whale fragments in relation to one another (for mapping purposes), only one portion of the dolphin genome was used.

\section{Biotin Labelling of Mitochondrial DNA Probe}

The probe DNA was labelled with biotin-7-dATP by nick translation using a nick translation kit purchased from Bethesda Research Laboratories (BRL, Gaithersburg, Maryland 20877 ) according to manufacturer's instructions. Five $\mu 1$ of a mixture containing $0.2 \mathrm{mM}$ each of dGTP, dCTP and dTTP, and $2.5 \mu l$ of $0.4 \mathrm{mM}$ biotinylated dATP were added to 
$2.0 \mu \mathrm{g}$ probe DNA. Sterile distilled water was added to a total volume of $45.0 \mu 1$. The solution was mixed briefly and $5.0 \mu 1$ of a solution containing 0.4 units $/ \mu 1 \underline{\text { E. coli }}$ DNA polymerase I and $40 \mathrm{pg} / \mu \mathrm{I}$ DNAse I was added. The solution was mixed briefly, centrifuged for a few seconds in a microcentrifuge to bring the liquid to the bottom of the tube, and incubated at $15^{\circ} \mathrm{C}$ for 90 minutes. The reaction was stopped by the addition of $5.0 \mu 1$ of $300 \mathrm{mM}$ EDTA $(\mathrm{pH} 8.0)$ and $1.25 \mu 1$ of $5 \%$ SDS. The DNA was then precipitated by the addition of $17.0 \mu 13.0 \mathrm{M}$ sodium acetate $(\mathrm{pH} 5.2)$ and $140.6 \mu 1$ cold absolute ethanol and then placed at $-20^{\circ} \mathrm{C}$ for $1 .-2$ hours. The DNA was pelleted by centrifugation at $10,000 \times \mathrm{g}$ for 30 minutes at $4^{\circ} \mathrm{C}$. The supernatant, containing unincorporated nucleotides, was carefully removed. Ethanol precipitation was repeated to ensure complete removal of unincorporated nucleotides. The DNA pellet was then vacuum dried and resuspended in $100 \mu 1$ TE (pH 8.0). Nick translated probe was stored refrigerated up to two weeks before use.

Since no homology was found between the plasmid pACYC 184 and the killer whale genome, the probe DNA fragments were not isolated from the plasmid prior to labelling. Homology of the labelled plasmid DNA to the Alu I restricted pBR322 marker allowed visualization of the marker following dye development of the blot. 
Radioactive Labelling of Mitochondrial DNA Probe

One southern transfer was run using a radiolabelled probe as a test to determine whether the biotin labelling system was as effective as radioactive labelling in producing similar results on Southern transfer. The whole dolphin mtDNA genome was labelled by the same nick translation procedure described above using $7.5 \mu 1$ (24 pmol, $75 \mu \mathrm{Ci}) \alpha-{ }^{32} \mathrm{P}$ dATP in place of biotinylated dATP. Following nick translation, unincorporated nucleotides were removed by gel filtration through a sephadex G-50 spun column (Appendix F; Maniatis et al. 1982).

The amount of $\alpha-{ }^{32} \mathrm{P}$ dATP incorporated during nick translation was calculated by trichloroacetic acid (TCA) precipitation using a modification of the procedure described by Maniatis et al. (1982). The protocol is given in Appendix $G$.

A total of $1.3 \times 10^{8} \mathrm{cpm}$ was added to the $45.0 \mu 1$ reaction. The amount of ${ }^{32} \mathrm{P}$ incorporated during nick translation was $1.8 \times 10^{6} \mathrm{cpm} / \mu 1$, giving an incorporation efficiency of $65.1 \%$. A total of $5 \times 10^{6} \mathrm{cpm}$ was used for hybridization in the southern transfer procedure.

\section{SOUTHERN TRANSFER PROCEDURE}

Restriction Endonucleases

All killer whale DNA samples were cleaved with fourteen restriction endonucleases. The enzymes used were: 
Alu I, Ava I, BamH I, Bgl II, Hae III, tha I, Hind III, Hinf I, Hpa II, Kpn I, Mbo I, Pvu II, RSa I and saug6 I. All enzymes were purchased through BRL and came supplied with $10 x$ reaction buffer. The recognition sequence for each enzyme is given in Table II.

Approximately $0.2-0.7 \mu \mathrm{g}$ of mtDNA was used for each restriction. The DNA sample was mixed with $1 / 10$ total volume of $10 x$ reaction buffer. Ten units of enzyme were added, with the exception of Saug6 I which required 18 units to obtain complete cleavage of the DNA. If necessary, sterile distilled water was added in order to keep the enzyme concentration at or below $1 / 10$ total volume. This prevented the glycerol contained within the enzyme mixture from interfering with the enzyme activity. The addition of water was also necessary to dilute the $10 \mathrm{x}$ reaction buffer to the appropriate $1 x$ concentration of salts. The samples were incubated at $37^{\circ} \mathrm{C}$ for $2-5$ hours. The length of time given for complete digestion to occur depended on the extent of activity for each enzyme (information provided by BRL). The reaction was stopped by the addition of $1 / 10$ volume of $10 x$ tracking dye [50\% (w/v) sucrose, $0.2 \mathrm{M} \mathrm{EDTA} \mathrm{pH} 8.0,0.25 \%$ ( $/ / \mathrm{v})$ bromophenol blue, $0.258(\mathrm{w} / \mathrm{v})$ xylene cyanol]. The restricted samples were then placed at $65^{\circ} \mathrm{C}$ for three minutes to prevent the binding of cohesive termini, immediately placed on ice to cool and loaded into the wells of the gel. 
TABLE II

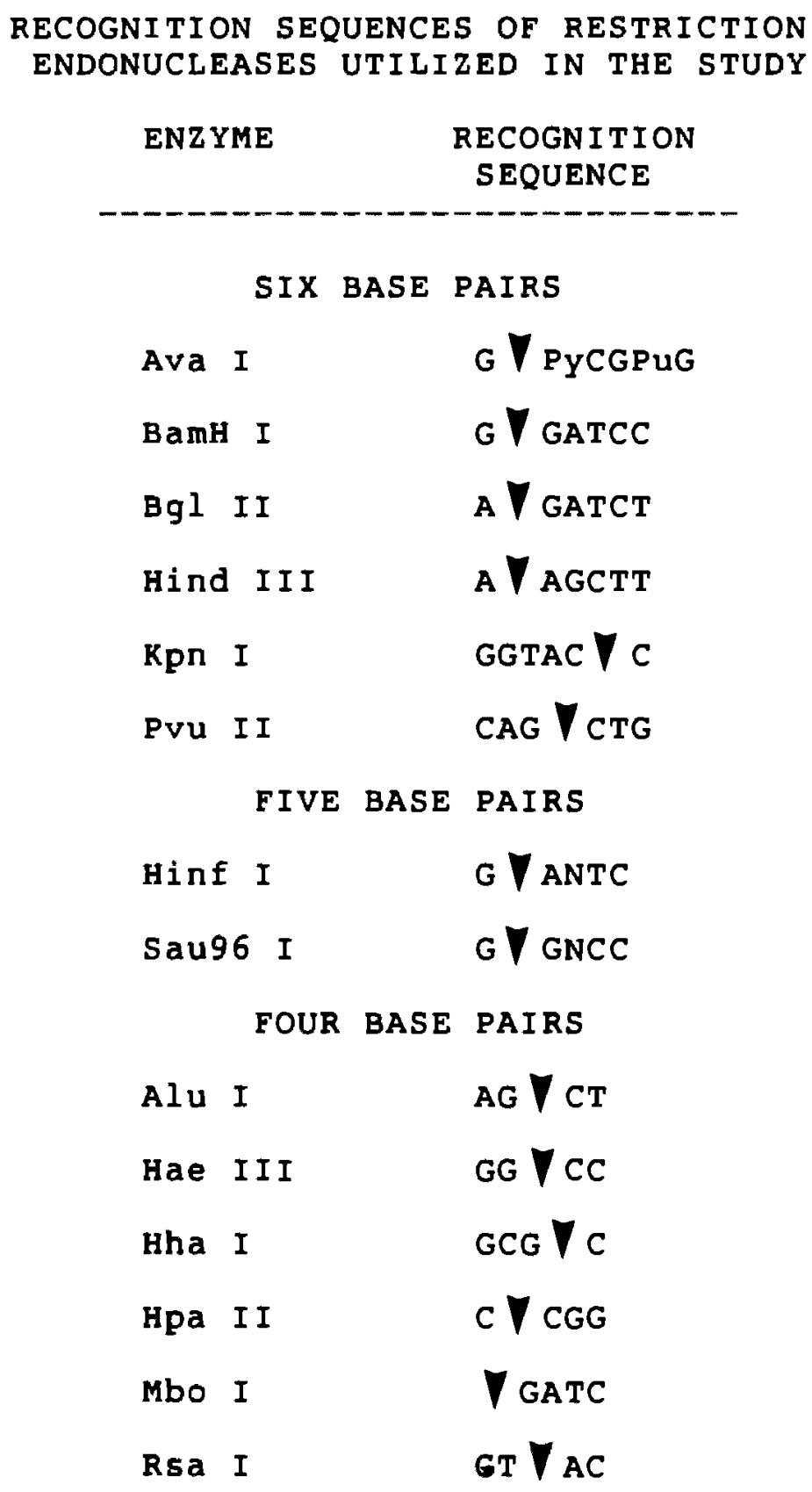


Ge1 Electrophoresis

Restricted DNA samples were loaded into the wells of horizontal agarose slab gels. Agarose concentrations varied from 0.6-2.08 in Tris-borate buffer 10.089 M Trisborate, 0.089 M boric acid, 0.002 M EDTA pH 8.0$)$ depending on the fragment sizes obtained by restriction. Larger fragments were run on low percentage gels, while smaller restriction fragments were run on higher percentage gels. The gels were submerged in Tris-borate buffer and initially run at 150 volts, 80 milliamps for 10 minutes to quickly move the DNA into the gel. They were then run at either 40 volts, 20 milliamps for $10-12$ hours or 80 volts, 40 milliamps for 5-6 hours.

Each gel was loaded with two known size markers along with the DNA samples. The two markers were biotinylated Hind III restricted lambda DNA and Alu I restricted pBR322. The fragment sizes obtained from these markers are shown in Figure 7 .

The Hind III restricted lambda DNA was purchased from BRL. The fragments were purchased end-labelled with biotin-7-dATP such that the fragments were visible on the membrane following dye development. Upon receipt of the lambda DNA, $\mathrm{NaCl}$ was added to a final concentration of 50 mM along with $1 / 10$ volume of tracking dye and stored refrigerated.

The plasmid pBR322 was obtained from R. Millette, 
a b

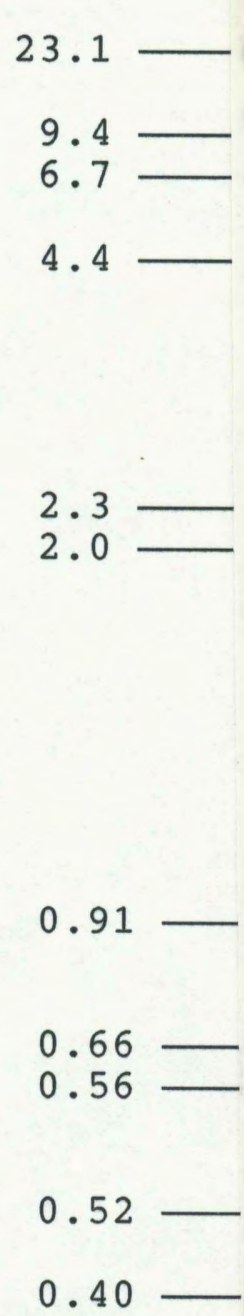


transformed into E. coli HBl01 cells following the procedure in Appendix $D$ and isolated from the cells using the protocol given in Appendix E. The DNA was then restricted with Alu I as previously described and stored refrigerated. Portions of pBR322 are present in the plasmid pACYC 184 which contains the dolphin probe DNA, thus hybridization of the probe to the marker occurred, allowing visualization of the marker in the final blot. Prior to use, the two markers were heated to $65^{\circ} \mathrm{C}$ for three minutes to prevent the binding of cohesive termini, cooled on ice and then $0.25-0.5 \mu \mathrm{g}$ of Hind III restricted lambda and $0.02 \mu \mathrm{g}$ of Alu I restricted PBR322 were loaded into separate wells of the gel.

\section{Southern Transfer}

Southern blots were performed by transferring the DNA from the agarose gels onto $10 \times 15 \mathrm{~cm}$ nylon membranes (purchased through Amersham, Arlington Heights, Illinois 60005). A non-radioactive nucleic acid detection kit (Blugene, BRL) was used for visualization of the biotin labelled dolphin mtDNA probe. The protocol is an adaptation of procedures provided by Amersham, BRL and Southern (1975), and is given in Appendix H.

One southern transfer was performed using a radioactively labelled dolphin mtDNA probe. The protocol given in Appendix $\mathrm{H}$ was followed up to step 32, except that 
$2.8 \mu 1\left(5 \times 10^{6} \mathrm{cpm}\right)$ of $\alpha-{ }^{32} \mathrm{P}$ dATP labelled probe was added to the hybridization solution rather than biotin labelled probe. The membrane was then allowed to air dry and autoradiographed at $-70^{\circ} \mathrm{C}$ for eight hours using Fugi RX type $x$-ray film placed between two intensifying screens.

\section{RESTRICTION FRAGMENT ANALYSIS}

\section{Fragment size Determination}

The size of the killer whale mtDNA restriction fragments were determined by comparing their relative mobilities with those of the two known-size markers. Since the distance travelled by a DNA fragment is inversely proportional to the $\log _{10}$ of its molecular weight (Maniatis et al. 1982), fragment size vs. fragment migration distance was plotted on semi-log graph paper for the two size markers. The migration distance of the mtDNA fragments was then measured and plotted on the graph to determine the fragment size that corresponded to that migration distance.

The movement of linear DNA fragments through an agarose gel is related to the electrophoretic mobility of the DNA and the gel concentration (Maniatis et al. 1982). For a given agarose gel concentration, only a certain size range of DNA fragments will be efficiently resolvable. This range corresponds to the linear portion of the above mentioned graph. Fragment sizes above or below this range cannot be efficiently determined using that specific 
agarose gel concentration. Therefore, it was necessary to vary the gel concentration depending on the fragment sizes obtained by restriction. For large-sized fragments, an agarose concentration of 0.6-0.98 was used, and for smaller fragment sizes, concentrations of $1.0-2.08$ were utilized. In this way, the fragment sizes obtained by restriction of the killer whale mtDNA could be determined with greater accuracy.

Restriction fragments smaller than 400 bp were not measured, as transfer of such small fragments onto the membrane is not efficient (Southern 1975).

Mapping of the Mitochondrial DNA Genome

A map was constructed of the sites at which specific restriction enzymes cleaved the mtDNA genome. Three Atlantic killer whales (AT1, $A T 6$ and $C B 1$ ) were chosen for use in determining the relative positions of restriction sites for various enzymes. The enzymes that were mapped include BamH I, Bgl II, Pvu II and Ava I. Two techniques were used for mapping purposes: simultaneous digestion with a combination of restriction enzymes followed by hybridization of the fragments to the whole dolphin mtDNA probe; and, simultaneous digestion with a combination of restriction enzymes followed by hybridization of the fragments to portions of the dolphin mtDNA probe. These methods, employed together, allowed the construction of a 
restriction map of the enzymes that recognize hexanucleotide sequences.

The restriction procedure used was similar to that described previously for single digests. The $10 \mathrm{x}$ restriction buffers used were the low, medium and high salt buffers of Maniatis et al. (1982). If the two enzymes were activated by the same buffer, they were added to the reaction at the same time. If two different buffers were required, the enzyme requiring the lower salt concentration was run to complete digestion. $\mathrm{NaCl}$ and/or $\mathrm{Tris}-\mathrm{HCl}(\mathrm{pH}$ 7.5) was then added to bring up the buffer salt concentration to that required by the second enzyme. The second enzyme was then added and incubated to complete cleavage.

The relative position of restriction sites was determined by comparing the single enzyme restriction digests with the double digests. Since the mtDNA genome is circular, the number of fragments produced by digestion with two enzymes should be the sum of the number of fragments produced by each enzyme singly. The fragments of each single digestion were aligned relative to one another such that the restriction sites of each enzyme when placed together produced the fragment pattern seen by double digestion. 
RESULTS

RESTRICTION FRAGMENT PATTERNS

Invariant Restriction Fragment Patterns

of the fourteen restriction endonucleases examined,

ten produced restriction patterns that were invariant among the whales tested. These included the six bp recognition site enzymes Ava I, BamH I, Bgl II, Kpn I and Pvu II; the five bp recognition site enzyme Hinf $I$; and the four bp recognition site enzymes tha I, Hpa II, Mbo I and Rsa I. Each enzyme will be dealt with separately in order to provide data on fragment sizes and other relevant information.

There were no Kpn I sites in the mtDNA genome of any killer whale examined. When DNA samples were restricted with this enzyme and probed with the Commerson's dolphin mtDNA, only one fragment resulted. To determine whether Kpn I linearized the killer whale mtDNA genome or did not cleave it at all, simultaneous digestions were performed with $\mathrm{Kpn} I$ and $B a m H ~ I, K p n ~ I$ and $B g l I I$, and $K p n I$ and Pvu II. In each case, the resultant restriction patterns were indistinguishable from those obtained by single enzyme digestion of BamH I, Bgl II and Pvu II respectively; therefore, Kpn I did not cleave the killer whale mtDNA at 
any position along the molecule.

Representative restriction fragment profiles of Ava I, BamH I, Bgl II and Pvu II are illustrated in Figure 8 . Ava I restriction produced four fragments of 6000,4300 , 3600 and 2550 bp for each killer whale examined. The four BamH I restriction fragments were $6950,5700,3250$ and 1040 bp in length. The enzyme Bgl II also produced four fragments that were $7430,4900,2860$ and 1080 bp in size. Pvu II restriction produced four fragments of 12,800, 2320, 1330 and 400 bp respectively. Hha I restriction produced seven fragments of $7600,2830,2000,1430,1300,1190$ and 490 bp (Figure 9).

The enzymes Hinf I, Hpa II, Mbo I and Rsa I also produced invariant restriction fragment profiles to the level resolvable by southern transfer. Each of these endonucleases produced a large number of fragments, many of which were below 400 bp in length. The small restriction fragments were not efficiently transferred onto the nylon membrane using the capillary blotting method that has been described; therefore, a portion of the mtDNA genome was not available for examination when these five enzymes were utilized. Although the restriction fragment patterns produced by these enzymes appeared to be invariant, the possibility exists that variation between killer whales may be present within the region of the mtDNA genome that could not be clearly resolved. 


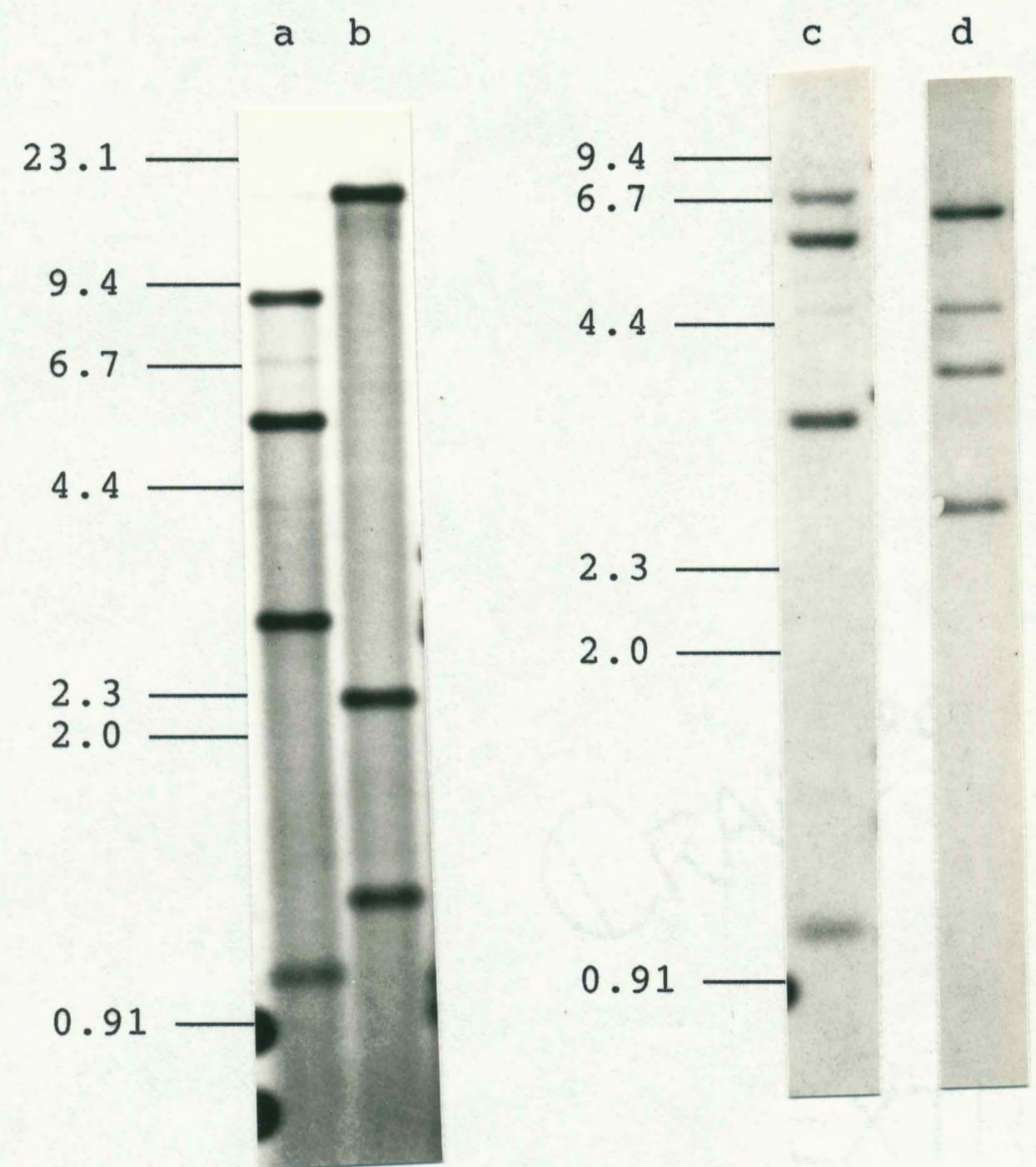

Figure 8. Invariant restriction fragment profiles of killer whale mtDNA. Bgl II (lane a) and Pvu II (lane b) restriction of whale AT1. BamH I (lane c) and Ava I (lane d) restriction of whale CB2. Size markers on the left hand side are given in $\mathrm{kb}$. 


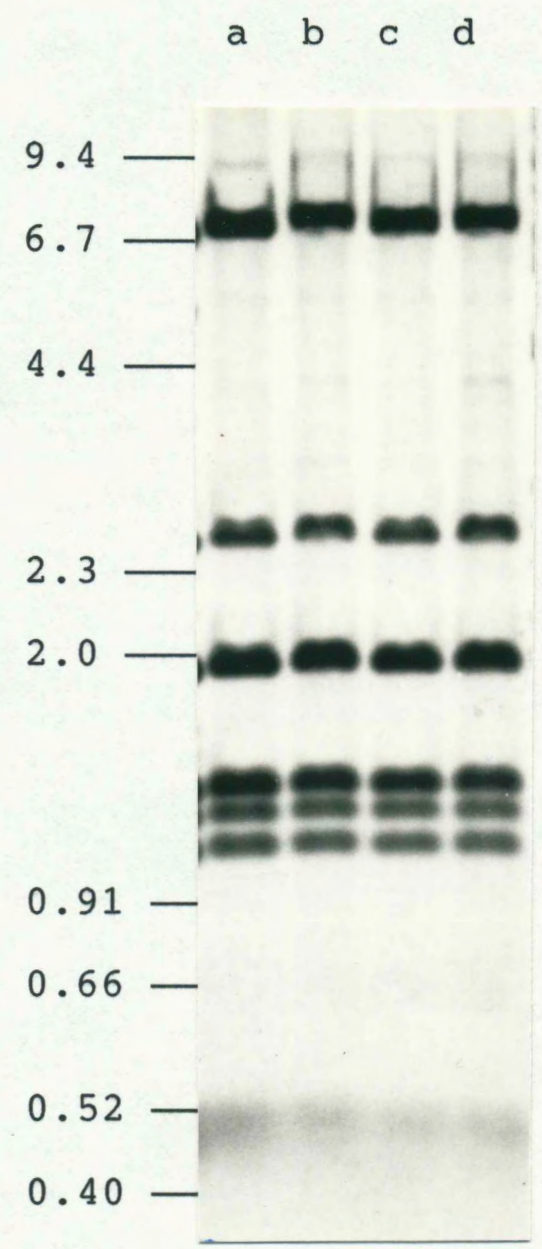

Figure 9. Restriction fragment profile of killer whale mtDNA cleaved with the enzyme tha I. Lane 1, S2; lane 2, PR3; lane 3, AT8; lane 4, AT9. Size markers on the left hand side are given in $\mathrm{kb}$. 
Restriction fragment patterns for Mbo I, Hpa II and Hinf I are shown in Figure 10. For the enzyme Mbo I, twelve restriction fragments were resolvable ranging from 5000-490 bp in length. These fragments constitute approximately $66 \%$ of the whole mtDNA genome. Hpa II restriction produced many fragments of which only nine were resolvable, making up $95 \%$ of the killer whale mtDNA genome. Fourteen Hinf I fragments were resolvable, ranging from 1400-400 bp in length. When the fragment sizes were added together, only $66 \%$ of the total genome could be accounted for. When the killer whale mtDNA was cleaved with Rsa I, eleven fragments could be distinguished (Figure 11). These fragments made up only $56 \%$ of the total genome, ranging from $1700-420$ bp in size.

\section{Restriction Fragment Pattern Variation}

Hae III. Restriction fragment pattern variation was seen when the four bp recognition site enzyme, Hae III, was used (Figure 12). All ten Atlantic killer whales as well as the two captive-born calves had the type 1 restriction fragment pattern. The fragment sizes were 1840,1490 , $1330,1230,1080,975,740,610,545,525,480$ and 410 bp respectively. Pacific killer whales that originated from the resident communities had a distinct Hae III restriction pattern (type 2) that was distinguishable from the Hae III type 1 profile by the presence of an extra fragment that 
a b c d e $\quad$ b $g$

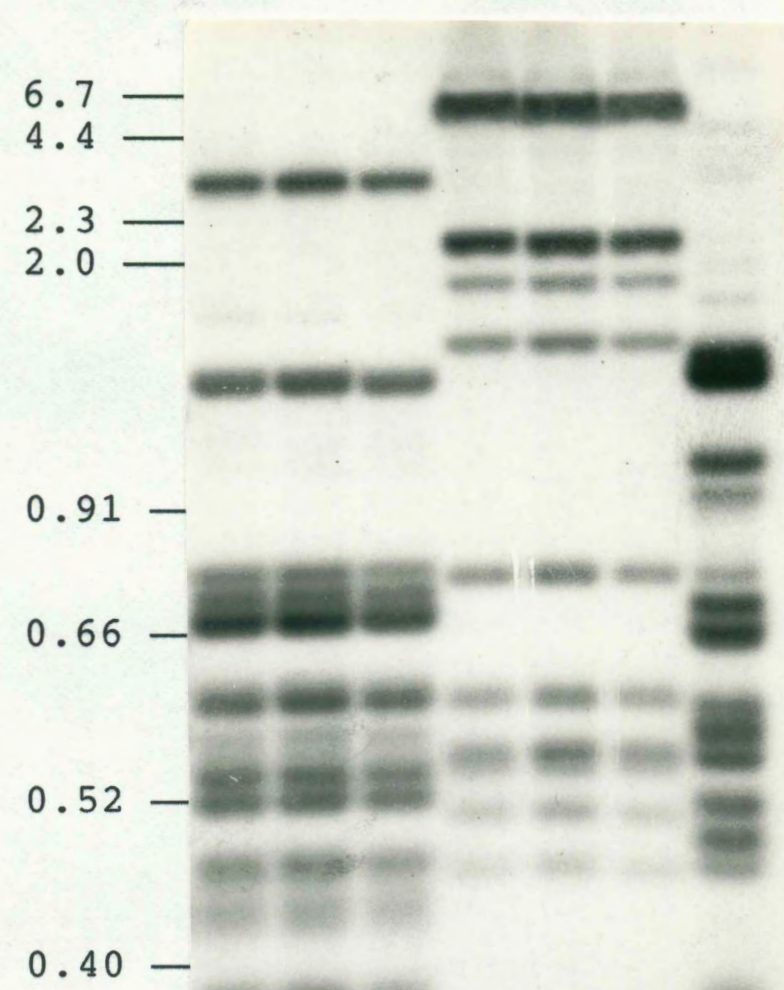

$0.40-$

Figure 10. Invariant restriction fragment profiles of killer whale mtDNA. Killer whales CB1 (lane a), PR3 (lane b) and T2 (lane c) cleaved with Mbo I; Hpa II restriction of whales CB1 (lane d), PR3 (lane e) and T2 (lane f); whale PR3 (lane g) cleaved with Hinf I. Size markers on the left hand side are given in $\mathrm{kb}$. 
a b c d e

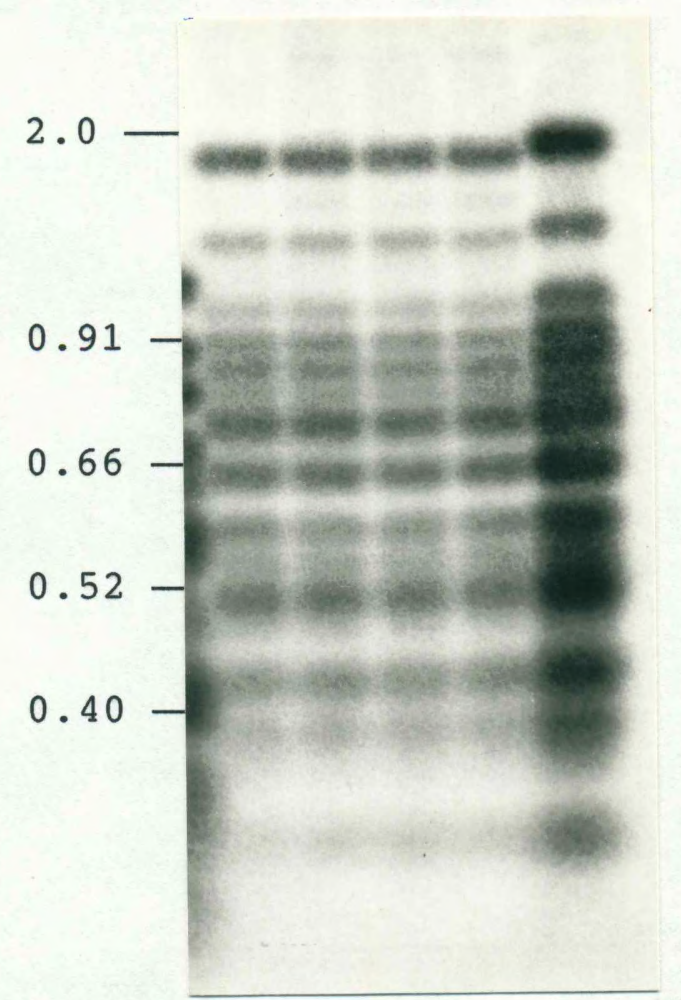

Figure 11. Restriction fragment profile of killer whale mtDNA cleaved with the enzyme Rsa I. Lane 1, PR1; lane 2, T1; lane 3, AT10; lane 4, АT3; lane 5, СB2. Size markers on the left hand side are given in $\mathrm{kb}$. 
a b c d e $f$

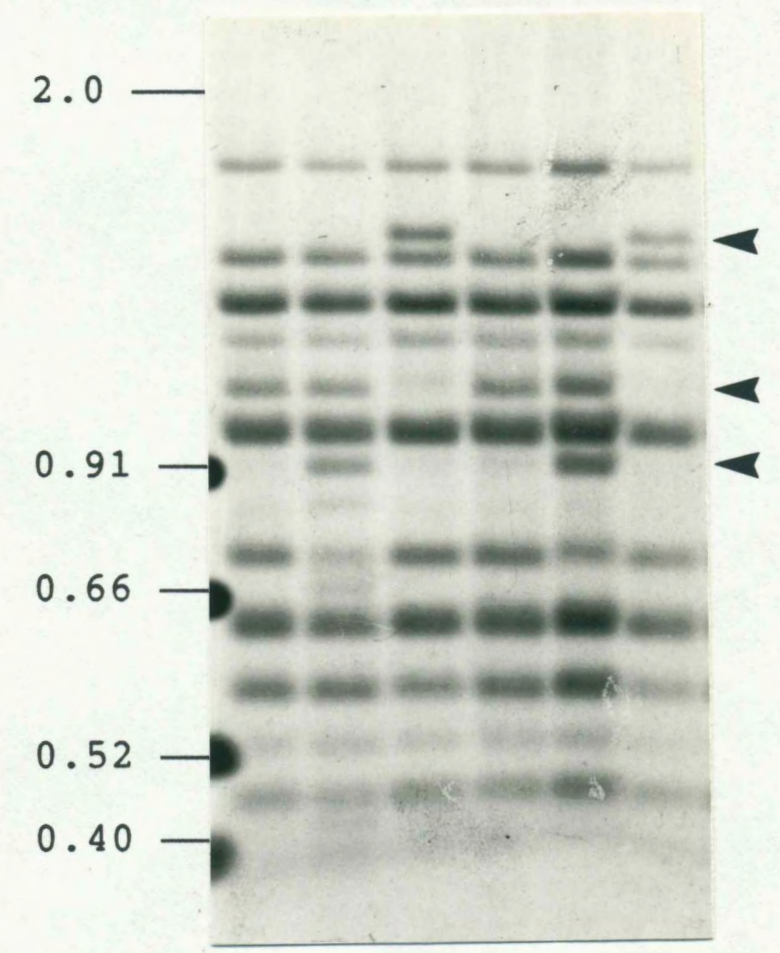

Figure 12. Restriction fragment profile of killer whale mtDNA cleaved with the enzyme Hae III. Lanes a (AT6) and d (AT7) are Hae III type 1 killer whales. Lanes b (PR1) and e (PR2) are Hae III type 2 killer whales. Lanes $c$ (T2) and f (T1) are Hae III type 3 killer whales. Size markers on the left hand side are given in $\mathbf{k b}$. Arrows indicate regions of variation. 
was $910 \mathrm{bp}$ in size. A third restriction fragment pattern, designated Hae II type 3, was seen in the Pacifickiller whales of transient origin and the two whales that stranded along the oregon coast. This profile differed from the type 1 and 2 patterns due to the presence of a $1580 \mathrm{bp}$ fragment and the absence of the 1080 bp fragment. The Hae II type 3 restriction pattern was also lacking the 910 bp fragment that distinguished the Hae III type 2 pattern from the Hae III type 1 pattern.

The southern transfer that was performed using radioactively labelled probe mtDNA contained representative animals from each of the three Hae III restriction fragment pattern types. As shown in Figure 13, the profiles obtained from this procedure are identical to those seen when biotin labelled probe is used (see Figure 12).

The three profiles produced by Hae III restriction do not encompass the whole mtDNA genome of killer whales. When the fragments are added together, the genome size ranges from 11,255 to 12,165 bp in length. This constitutes only $68-73 \%$ of the total killer whale mtDNA genome, indicating that some of the fragments may actually be two or more similarly sized fragments and/or many small fragments are produced by Hae III digestion that could not be resolved through the southern transfer procedure that was utilized.

Sau96 I. When the killer whale mtDNA was restricted 
a b c

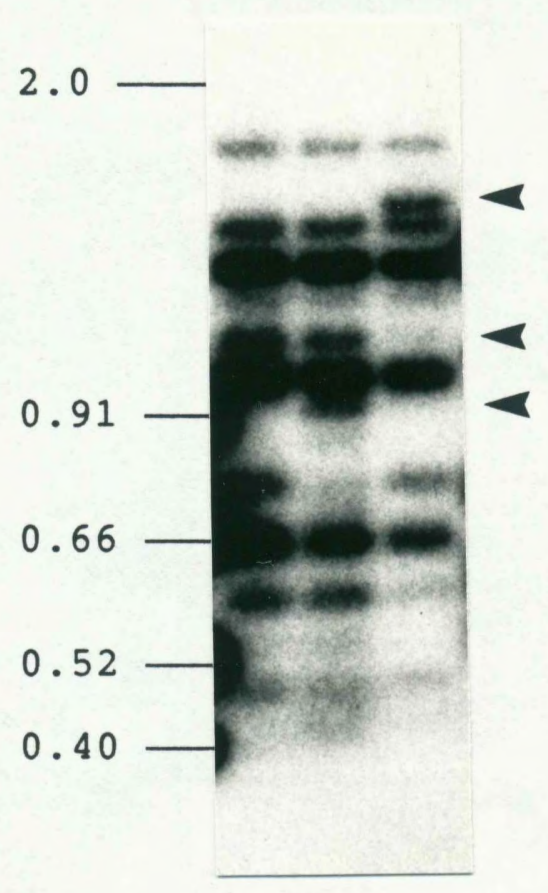

Figure 13. Restriction fragment profile of killer whale mtDNA cleaved with the enzyme Hae III. The Commerson's dolphin mtDNA prgbe used in hybridization was labelled with $\alpha-32 \mathrm{P}$ dATP. Lane a, AT7, type 1; lane b, PR1, type 2; lane c, T1, type 3. Size markers on the left hand side are given in $\mathrm{kb}$. Arrows indicate regions of variation. 
with sau96 I, two distinct fragment patterns were obtained (Figure 14). The first profile, shown as type 1, was found in all killer whales of Atlantic origin, the two captiveborn calves, and in all killer whales of Pacific origin that originated from resident pods. The fragment sizes were $3300,2880,2690,940,910,800,600,575$ and 520 bp in length to give a total of $13,215 \mathrm{bp}$. The saug6 I type 2 pattern was seen in the Pacific killer whales of transient community origin and in the two stranded animals. This pattern was distinguishable from the sau96 I type 1 profile due to the presence of a 1020 bp fragment and the absence of the 800 and 520 bp fragments. Therefore, the Sau96 I type 2 pattern consisted of fragments that totalled $12,915 \mathrm{bp}$. As was seen w⿳亠丷厂犬th Hae III restriction, and several of the invariant enzymes, only a portion of the killer whale mtDNA genome was available for examination. Further variation almost certainly exists within the fragments that are below 400 bp in length due to the fact that the two missing fragments in the sau96 I type 2 restriction profile are not completely accounted for by the extra fragment at $1020 \mathrm{bp}$.

Alu I. Similar restriction fragment pattern differentiation to that described for Sau96 I was observed using the enzyme Alu I. As shown in Figure 15, two distinct restriction patterns were seen. The Alu I type 1 fragment profile occurred in all killer whales from the 
a b c d e $f \quad g$

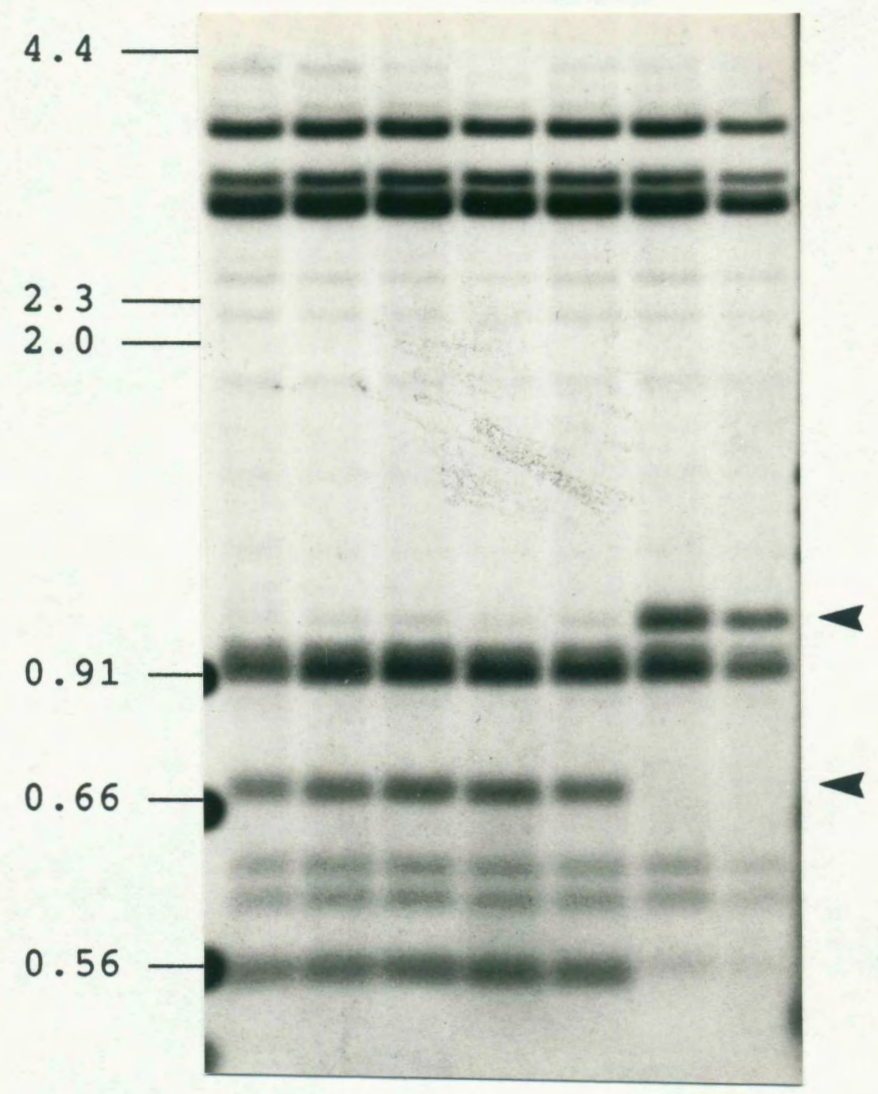

Figure 14. Restriction fragment profile of killer whale mtDNA cleaved with the enzyme saug6 I. Lanes a through e are type 1 animals AT5, CB1, PR3, PR5 and AT2 respectively. Lanes $f$ and g are type 2 animals $\mathrm{T} 2$ and $\mathrm{T} 1$ respectively. Size markers on the left hand side are given in $\mathrm{kb}$. Arrows indicate regions of variation. 
a b c

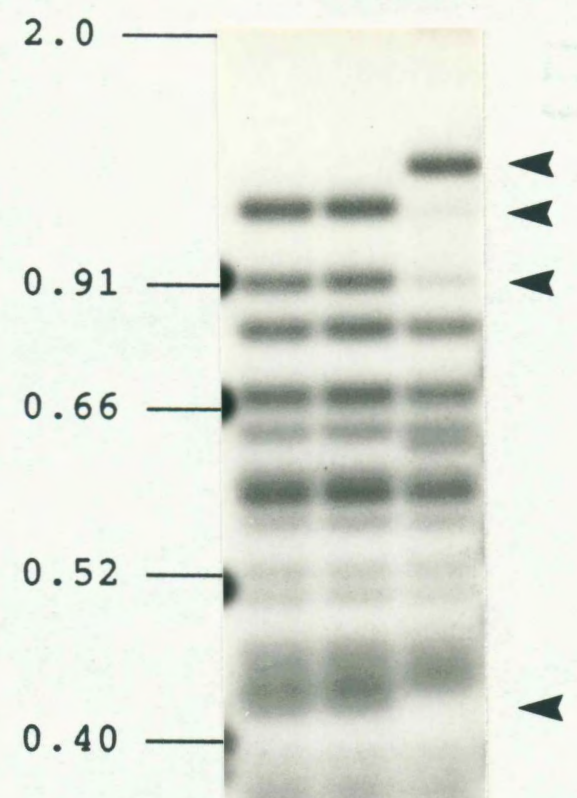

Figure 15. Restriction fragment profile of killer whale mtDNA cleaved with the enzyme Alu I. Lanes $a$ and $b$ are type 1 animals AT5 and PR4 respectively. Lane $c$ is type 2 whale $T 2$. Size markers on the left hand side are given in $\mathrm{kb}$. Arrows indicate regions of variation. 
Atlantic Ocean, the two captive-born calves and the five Pacific resident community whales. The fragment sizes were $1080,945,815,710,660,580,520,465$ and $440 \mathrm{bp}$. The transient animals and the two stranded killer whales exhibited the Alu I type 2 restriction profile which lacked the 1080 and 945 bp fragments but had an extra fragment of 1250 bp in size. The restriction fragment profiles obtained from Alu I cleavage account for only approximately 358 of the whole killer whale mtDNA genome; therefore, a large number of the fragments produced by this enzyme remained undetected. More variation between killer whales may be present within these small, undetected fragments.

\section{Hind III Restriction}

A problem was experienced when the enzyme Hind III was utilized. It was very difficult to get complete and reliable restriction of the DNA when using this enzyme, although a variety of restriction conditions were attempted in order to try and alleviate the problem. The restriction conditions that were tried included varying the amount of time allowed for restriction to proceed, varying the salt buffer conditions, using Hind III enzyme from several different manufacturers (including BRL, Amersham and ICN) and varying the enzyme concentration. In each case, bacteriophage lambda was also subject to the same restriction conditions to act as a control indicator of 
cleavage. While the lambda DNA was consistently restricted to completion and produced the expected fragment pattern, the killer whale mtDNA produced patterns that varied depending on the restriction conditions utilized and was rarely comparable even though the same animal was used for each test (Figure 16). Due to the inconsistency of this enzyme, Hind III was not used for restriction fragment pattern examination.

\section{GENOME SIZE ESTIMATION}

The restriction fragment profiles of five enzymes were particularly useful for killer whale mtDNA genome size estimation. These enzymes were Ava I, BamH I, Bgl II, Hha I and PVu II. The fragment sizes obtained by restriction were added together to obtain a size estimate for each enzyme. By averaging these values, the mtDNA genome for killer whales was estimated to be approximately $16,600 \pm$ 400 bp in length. This value represents, to my knowledge, the first estimate of mtDNA genome size reported for killer whales and is within the range of $16,500 \pm 200$ bp reported for the mtDNA of other mammalian species (Brown 1983).

MAP OF THE KILLER WHALE MITOCHONDRIAL DNA GENOME

A restriction site map was constructed for the four restriction enzymes Ava I, BamH I, Bg1 II and Pvu II (Figure 17). The other ten enzymes were not mapped, as 
a $\quad$ b $\quad c \quad d$

$23.1-$

$9.4-$

$6.7-$

4.4

는 $=$

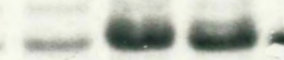
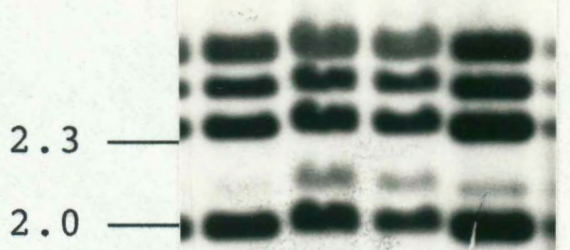

$0.91-$

$0.66-$

$0.52-$

$0.40=$

Figure 16. Hind III restriction patterns of killer whale AT8 obtained due to alteration of reaction conditions. Lane a: conditions as described in text. Lane b: low salt buffer of Maniatis et al. (1982). Lane c: enzyme from Amersham. Lane d: BRL high concentration enzyme (70 units $/ \mu 1)$. Size markers on the left hand side are given in $\mathrm{kb}$. 
simultaneous digestion of these enzymes produced many small fragments that could not be visualized using the southern transfer technique. 


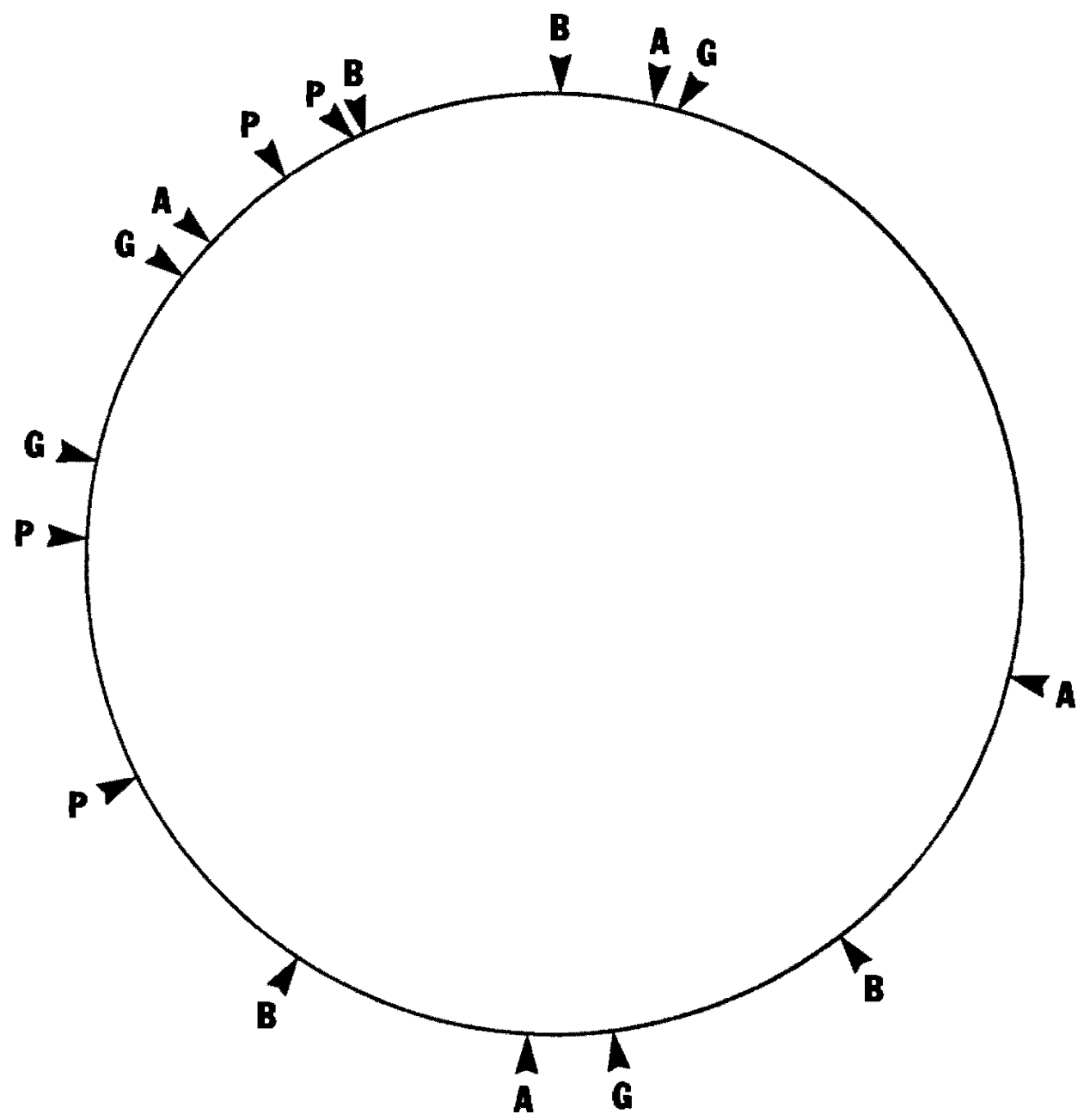

Figure 17. Restriction map of the $16.6 \mathrm{~kb}$ killer whale mtDNA genome. $A=$ Ava I sites; $B$ = BamH I sites; G = Bgl II sites; P = Pvu II sites. 


\section{DISCUSSION}

\section{POPULATION CHARACTERIZATION}

Although the level of variability between the mtDNA restriction fragment profiles of killer whales from different populations was low, mtDNA variation can be used to characterize killer whale populations. Three restriction endonucleases have thus far been shown to differentiate between the killer whales that have been examined. The mtDNA restriction fragment patterns produced by Hae III digestion were effective in discriminating both between Atlantic and Pacific whales and among the Pacific animals. The enzymes Sau96 I and Alu I both produced restriction fragment profiles that distinguished killer whales of the Pacific transient community from the Pacific resident community and the Atlantic population.

The two captive-born calves exhibited the same restriction fragment profiles as their Atlantic origin mothers for all enzymes examined, even though in both cases the fathers were of Pacific origin (see Figure 14). This was to be expected due to the maternal mode of inheritance of the mtDNA genome. Confirmation of this in killer whales allowed the calves to be placed into the category of Atlantic origin whales. 
The inclusion of the two stranded killer whales from the oregon coast as transient by mtDNA type extends the potential range of this community beyond the vancouver Island area. Indeed, recordings of killer whale vocalizations indicate that killer whales found along the coast of North America all have a dialect which is similar to that of the transient community of the vancouver Island region (J. Ford, pers. comm.). The two stranded animals will therefore be considered as being of transient origin for the purposes of this discussion.

Mitochondrial DNA Variability

The degree of mtDNA polymorphism was surprisingly low in killer whales, with only three of the fourteen restriction endonucleases exhibiting variability between animals. Other mammalian species, as well as birds, fish and reptiles (Avise et al. 1987) all appear to show a greater degree of intraspecific mtDNA variation than was seen in killer whales. For most of these organisms, mtDNA restriction pattern variation can be seen when using six bp recognition site enzymes. For the killer whales, it was necessary to examine the mtDNA genome using four and five bp recognition site enzymes in order to find polymorphisms, and many of these enzymes did not appear to exhibit any variability.

All killer whales of Atlantic origin exhibited the 
Hae III type 1 pattern. The type 1 pattern was easily distinguishable from the two mtDNA patterns that were seen in the Pacific animals (Figure 12).

A subset of the same killer whales that were used in this study was found to exhibit similar variation in blood lactic dehydrogenase (LD) levels (Cornell 1983). Killer whales of Pacific origin showed consistently lower LD values than those of Atlantic origin. This is possibly indicative of genetic differentiation between the populations of killer whales from the Atlantic and Pacific oceans. Cornell (1983) also found similar intraspecific variation in the LD levels of wild populations of bottlenose dolphins (Tursiops truncatus) from different geographic areas.

The Hae III mtDNA restriction fragment profiles of the Pacific killer whales used in this study differentiated whales that originated from resident community pods (Hae II type 2) from those of the transient community pods (Hae III type 3). This division agrees with that of Bigg (1982), who split the killer whales in the vancouver Island region into resident and transient communities based on behavioral data.

A comparison of haematology and blood chemistry values of the Pacific origin killer whales that were used in the present study has shown that some animals exhibit significantly and consistently higher values in 
haemoglobin concentration, packed cell volume and red blood cell counts (Cornell et al. 1981). These values suggest that there may be differentiation between coastal (resident) and off-shore (transient) killer whales. Similar haematological variation has also been observed between coastal and off-shore forms of bottlenose dolphin (Duffield et al. 1983).

The restriction fragment patterns produced by both Saug6 I and Alu I restriction differentiated the transient killer whales from the rest of the animals examined. The fact that the Atlantic and Pacific resident killer whales have the same Saug6 I and Alu I restriction patterns suggests that killer whales from these two groups are matrilineally more closely related to each other than either is to the killer whales of transient origin. This is interesting, considering that resident and transient communities of Pacific killer whales inhabit the same waters for much of the time and are often observed in close proximity to each other (Bigg 1982).

On the basis of mtDNA fragment patterns, it appears that the resident and transient communities of Pacific killer whales form two distinct maternally-based assemblages. Due to the maternal mode of mtDNA inheritance, mtDNA analysis does not address the issue of whether reproductive isolation exists between the various groups of killer whales that have been examined. It does 
not provide any information regarding the reproductive activities of males within and/or between the groups. Rather, it supports the concept of distinction between whales along maternal lineages. This is consistent with the theory, based on observational data, that pods and pod communities, particularly as defined for killer whales in the British Columbia and washington area, are structured around a social system composed of groups of maternally related whales (Bigg 1982; Heimlich-Boran 1986; Bigg et al. $1987)$.

Mitochondrial DNA Lineage Extinction

The information obtained from mtDNA analysis represents the history of evolutionary change within a maternally transmitted piece of DNA that can only differentiate through mutational events. It is important to keep this in mind, as it stresses the fact that such information does not provide a complete picture of the phylogenetic history of a species. Only half of the maternal nuclear genome is transmitted to the offspring and the mechanism of recombination can complicate the amount of maternal nuclear DNA that is passed on. The proportion of nuclear DNA originating from the mother decreases each generation thereafter, while the mitochondrial genome remains relatively unaltered.

statistical models of mtDNA evolution must take into 
account the asexual mode of transmission of mtDNA within an otherwise sexually reproducing species. It has been suggested that, due to the mode of inheritance, random extinction of mtDNA lineages within a population can occur rapidly. The result of this would be to increase the probability that organisms within a population appear to have a common maternal ancestor within a relatively short length of time. Avise et al. (1984b) estimated the probability of survival of two or more independent mtDNA lineages over time. It was found that if $n$ adult females within a stable population produce daughters according to a Poisson distribution with mean $(\mu)$ and variance (v) equal to 1.0 , then within about $4 \mathrm{n}$ generations all individuals in the population will, with high probability, trace mtDNA patterns back to a single female ancestor. The length of time for this to occur decreases if the variance in progeny survival between females is higher, a situation which is more likely to occur in wild populations of organisms. In species which have historically high levels of gene flow, mtDNA lineage extinction may in part account for the low levels of mtDNA variability that are seen (Avise et al. $1987)$.

Mitochondrial DNA Evolutionary Rate

The apparent lack of extensive mtDNA polymorphism between killer whales may be due to a deceleration in the 
evolutionary rate of the killer whale mtDNA genome in comparison to other mammalian species. This theory has been proposed for several vertebrate species that also exhibit low levels of mtDNA variability (Avise et al. $1988)$.

Marine mammals have undergone extreme evolutionary adaptations for life in the marine environment. Many of the physiological processes in marine mammals (i.e. respiration) may be under some form of environmental pressure. Since the function of the mtDNA genome is to produce several components of the respiratory chain, selective pressure on the respiratory processes of marine mammals may be such that constraints on mtDNA activities are greater in these animals than in terrestrial organisms. It is possible that alterations of the mtDNA which would not affect terrestrial organisms cannot be tolerated by marine mammals.

\section{Intraspecific Phylogeography}

Many studies have been conducted to examine mtDNA variation in wild populations. The results of these studies have illustrated trends that appear to divide the pattern of mtDNA polymorphisms within a species into two major groups. In one group, mtDNA analysis separates the species phylogenetically into subgroups (or populations) which are geographically structured. The other group 
consists of those species that tend to exhibit a limited amount of geographic population structuring.

A new discipline has arisen from these studies which utilizes both population genetics and phylogenetic systematics to determine the relationships between organisms at the intraspecific level. Avise et al. (1987) has termed this discipline "intraspecific phylogeography". Under this heading, the two groups described above have been divided into five categories which attempt to connect the geographic patterns of mtDNA variation within a species to possible evolutionary circumstances that may have led to the patterns that are reen. The underlying feature of each category is the level of extrinsic (zoogeographic) barriers to gene flow within a species.

In category $I$, there have been long term extrinsic barriers to gene flow between populations such that each population is genetically discrete and geographically structured. This can be seen in fresh water fishes which inhabit separate river drainages (Bermingham and Avise 1986) and in pocket gophers (Avise et al. 1979).

Category II includes those species which have widely divergent mtDNA genotypes, where there is no current geographic separation between the populations. Geographic barriers to dispersal that once existed are no longer present and the populations are now intermixing. An example of this includes hybrid swarms of bluegill sunfish 
(Avise et al. 1984a).

In category III, the changes in mtDNA are gradual over a specific geographic range, indicating a historically limited amount of genetic exchange between adjacent populations.

Categories IV and $\mathrm{V}$ are similar. They both assume that the species has a life history conducive to dispersal and have occupied ranges relatively free of extrinsic barriers to dispersal. The major difference between the categories is in the degree of gene flow that has occurred within the species.

Category IV assumes that there has been extensive gene flow within the species during recent evolutionary time. The various mtDNA genotypes are not geographically localized but are widespread throughout the range of the species. Avise et al. (1987) suggest that birds, flying insects, marine fishes and to some extent humans fall into this category.

In category $V$, the species has had historically intermediate levels of gene flow between populations. Ancestral mtDNA genotypes therefore occur over a wide area of species range. Interspersed with the ancestral genotypes are localized mtDNA genotypes that have arisen more recently from the ancestral type and have not yet spread throughout the range of the species.

The intraspecific phylogeographic pattern of mtDNA 
variation in the killer whales could fall into either categories IV or $V$. The limited amount of information available regarding killer whale movement patterns and the full extent of mtDNA diversity within the species prevents the assignment of one category over another. There are no firm zoogeographic barriers to the movement of killer whales between and within oceans. The low level of mtDNA variation seen in the killer whales examined (eleven of the fourteen restriction enzymes utilized exhibited no variation) suggests that, based on these models, there has been recent gene flow between the various groups. In the case of animals from the Atlantic and Pacific oceans, at least two corridors of exchange exist: one around the southern tip of South America and the other through the Arctic Ocean which is accessible in the summer months. It is unlikely that the populations in the two oceans are panmictic but occasional long distance migration of individuals or groups of killer whales cannot be disregarded. Whether recent historical levels of gene flow were extensive or intermediate is not known.

The form of exchange suggested in category III cannot be discounted either. Since killer whales are found in every ocean there is the possibility that genetic exchange is occurring in a gradual fashion between adjacent populations. This would create a flow of genetic material between the oceans that could act to decrease genetic 
differentiation between populations, thus making the species more uniform. If a portion of this exchange involves females moving from one region to another it could account for the low level of mtDNA variation seen between killer whales of the two oceans.

\section{Chromosomal Evolution of Killer whales}

The rate of chromosomal evolution in killer whales has been faster than that seen in other cetacean species whose rate of chromosomal change has been conservative (Arnason 1974; Duffield 1986). This increased rate has been attributed to differences in the population structure and social organization of killer whales with respect to their breeding system (Duffield 1986). As explained by wilson et al. (1975), several factors are necessary for a chromosomal mutation to become rapidly fixed in a population. First, the gene rearrangement must be present in a small population of ten or less breeding individuals. These individuals must remain reproductively isolated from other members of the species for at least two generations. During this time a chromosomal mutation can become fixed in the homozygous condition through inbreeding within the small population, provided that the genetic change does not dramatically alter the viability of the heterozygote and confers some advantage to the homozygote.

The social structure of killer whales suggests that 
this species could have undergone chromosomal evolution in a manner similar to that described above. Pods of killer whales consist of related individuals. Occasionally, members of the pod may split off from the main group to form a new pod (Ford and Fisher 1982). Over time, the structure of pods in a given area would consist of distantly related whales that may begin to breed with each other. This could lead to a certain amount of inbreeding that would $f i x$ chromosomal alterations within the population. This process could be enhanced by the existence of dominance hierarchies among males (wilson et al. 1975) or females, such that only a few of the individuals in the population are contributing genetically to the next generation.

Dominance Hierarchies Among Killer whales

Observations of captive killer whales have shown that females tend to join together into groupings similar to that of pods in the wild (D. Duffield, pers. comm.). Within these groups, dominance hierarchies appear to be formed and calves are produced by the dominant females. Lesser females are prevented from having offspring. If one examines this information in terms of wild populations of killer whales, it may be that each pod within a community forms dominance hierarchies between the related females of the pod. Another possibility is that dominance hierarchies 
are formed between pods or subpods of a community, such that certain pods or subpods consist of dominant females producing offspring while other pods or subpods contain subordinate females that do not breed.

\section{A MODEL OF KTLLER WHALE EVOLUTION}

The occurrence in killer whales of a high rate of chromosomal change coupled with a slow rate of mtDNA evolution may be a product of their social structure and population dynamics. Presented here is a model of possible interactions between individuals and pods of killer whales that could lead to the variable evolutionary rates of the nuclear and mitochondrial genomes. The model is based on current knowledge of the genetics, population structure, movement patterns and social interactions of killer whales. The major factors used in the construction of this model have already been presented in this paper.

The basic premise of the model is that if a limited number of dominant females are contributing to the next generation, then the mtDNA composition of the population will remain relatively homogeneous, while chromosomal alterations that occur in those females have a greater chance of becoming fixed in the population.

For the model, let us assume that two populations of killer whales exists (A and B). All whales in population $A$ have a single mtDNA type and a variety of chromosomal 
types. The same applies to population $B$ so that the nuclear and mitochondrial DNA composition of each population is different. Assume that an individual female or a pod of males and females $(x)$ belonging to population $A$ moves to a new area inhabited by population $B$. The animals from group $x$ begin to reproduce with individuals from population B. Both the nuclear and mitochondrial DNA of group $x$ from population $A$ will become incorporated into population B. Nuclear DNA variation would slowly spread through population $B$ in the heterozygous condition from males originating from group $x$. Before these chromosomal changes can become fixed in population B, sufficient time must elapse for the pods of population $B$ to consist of distantly related group $x$ animals that begin to breed with one another.

The spread of the mtDNA variant of group $x$ would occur faster than that of the nuclear DNA. The group $x$ mtDNA variant would immediately become incorporated into population $B$ through breeding females and their female offspring. As new pods are established by female descendants of group $x$, the mtDNA variant spreads within population $B$ so that the population has two mtDNA types: that of population $B$ and that of group $x$. This effectively decreases the mtDNA variability between population $B$ and population A since both populations have now incorporated the group $x$ mtDNA type. To apply the statistical model of 
Avise et al. (1984b), the probability that both populations $A$ and $B$ will eventually trace mtDNA ancestry back to a single female from group $x$ is fairly high. If extinction of the original population B mtDNA type occurs, then both populations $A$ and $B$ will have the same mtDNA type (that of group $X$ from population $A$ ). Low level mtDNA variation between the two populations would be the result of random mutations of the mtDNA genome occurring within the females of each population.

If the movement of killer whales between populations occurs fairly often (in evolutionary terms), then the spread of genetic material would be rapid. If a scenario such as the one described above were to occur, it could account for the high level of chromosomal variability and the low degree of mtDNA polymorphism seen in killer whales from different geographic locations.

The observed mtDNA restriction pattern profiles for killer whales may be an indication of genetic interactions between groups of whales such as those described in the model. The Saug6 I and Alu I patterns could be the result of recent historical genetic exchange between the Pacific resident and Atlantic populations such that the type 1 mtDNA variant was incorporated into both groups. Soon after this, the mtDNA alteration(s) that distinguish these two groups (as seen through the Hae III restriction fragment profiles) may have occurred. Thus the Atlantic 
population would exhibit the type 1 Saug6 I, Alu I and Hae III restriction patterns, while the Pacific resident community would have the same Sau96 I and Alu I pattern but a different Hae III restriction profile.

Exchange between female killer whales of the Pacific transient community and whales from other groups may not have occurred recently. This would have allowed a greater number of mutations to accumulate in the mtDNA genome of the transient group independently of the other killer whale populations and could account for the differences in the restriction fragment profiles of Sau96 I, Alu I and Hae III that were observed for this community. Alternatively, the transient group may have undergone random mtDNA lineage extinction, leaving a mtDNA genome type that was slightly different from that of the other two groups.

\section{HIND III STAR ACTIVITY AND INACTIVATION}

It has recently been found that certain type II restriction endonucleases decrease their substrate specificity under modified conditions (Brooks and Roberts 1982; Nelson and McClelland 1987). Hind III is known to cleave degenerate sequences (known as star activity) under conditions of high $\mathrm{pH}$, lowered ionic strength, substitution of the metallic cofactor required for activation of the enzyme and in the presence of organic solvents such as glycerol and ethanol (Nasri and Thomas 1986). It has also 
been suggested that incomplete digestion of DNA by Hind III may be due in part to the rapid inactivation of this enzyme in reactions (Nasri and Thomas 1986). Since cleavage of the killer whale DNA with Hind III under a variety of conditions did not appear to alleviate the problem, it is questionable whether the anomalous mtDNA restriction patterns observed with Hind III were the result of star activity. A more likely explanation involves the inactivation of Hind III prior to complete digestion. If this were the case, then alteration of the reaction conditions would not have affected Hind III restriction to any great extent.

Hind III is sensitive to methylation of the $5^{\prime}$ adenine and cytosine residues within its recognition sequence (Nelson and McClelland 1987). The variable Hind II restriction patterns seen between killer whales may have been due in part to differences in methylation between animals, although this does not explain why variation was seen between restriction digests of the same animal.

\section{FUTURE GENETIC ANALYSIS OF KILLER WHALES}

It should be noted that further investigation into the population dynamics and genetics of killer whales is necessary in order to determine the accuracy of the model and the other hypotheses that have been put forward in this paper. Techniques are now at hand to permit extensive 
examination into the various aspects of killer whale behavior, reproduction and genetics that may provide answers to the questions regarding the population structure and evolution of killer whales.

of the ten invariant enzymes examined, the possibility exists that at least four of them may exhibit variation between killer whales if a more detailed examination is undertaken. Polyacrylamide gel electrophoresis coupled with electrophoretic transfer of restriction fragments onto nylon membranes would allow for visualization of fragments under 400 bp in length. This method may also reveal a greater amount of variation between killer whales by separating similar sized fragments into discrete bands. Analysis of the restriction fragments by densitometry would also help to determine whether each band is a single fragment or whether it consists of two or more fragments that are similar in molecular weight.

These procedures should be applied to the three variable endonucleases as well so that complete restriction fragment profiles can be determined. Examination of the smaller restriction fragments would allow a more detailed analysis of killer whale mtDNA variation and may provide a level of variability that would distinguish between killer whale pods within a single community.

The application of these genetic techniques to wild populations of killer whales may help to determine the 
intra- and interpod relationships between killer whales in the Vancouver Island area. Extension of this into other regions such as Alaska where "resident" and "transient" pods of killer whales have also been identified (Leatherwood et al. 1984) and the Atlantic ocean may provide answers regarding the population structure of killer whales within the oceans of the world. 


\section{CONCLUSIONS}

The analysis of killer whale mtDNA revealed that genetic differentiation has occurred between geographically separated populations of this species. Animals from the Atlantic Ocean could be distinguished from killer whales of the Pacific Ocean on the basis of Hae III restriction fragment polymorphisms. Further variation in the Hae III restriction fragment profile indicates that genetic differentiation also exists between resident and transient killer whales of the Pacific Ocean. MtDNA variation was also seen using the enzymes Saug6 I and Alu I. These two enzymes distinguished Pacific transient killer whales from both the Atlantic and Pacific resident groups.

Since mtDNA analysis follows the history of a maternally transmitted piece of DNA, the mtDNA variation that has been observed does not necessarily imply current reproductive isolation between these three groups of killer whales. No information can be inferred regarding the movement of males between and within populations, although the results do indicate separation of the groups along maternal lines.

The amount of mtDNA variation between these three groups of killer whales is extremely low, indicating either that the rate of killer whale mtDNA genome evolution has 
been decelerated in comparison to other mammalian species, or that mitochondrial genetic exchange between the groups has occurred during recent evolutionary history. Based on the mtDNA restriction patterns, it appears that exchange between females of the pacific resident community and the Atlantic population has occurred more recently than exchange with females of the Pacific transient community.

A more detailed analysis of the mtDNA genome of killer whales could prove valuable for the further definition of killer whale populations, their geographic distribution patterns and the relationships between pods of killer whales within populations. 


\section{REFERENCES}

Adams, J. and Rothman, E.D. 1982. Estimation of

Phylogenetic Relationships from DNA Restriction Patterns and Selection of Endonuclease Cleavage Sites. Proc. Natl. Acad. Sci. USA. 79:3560-3564.

Anderson, S., Bankier, A.T., Barrell, B.G., de Bruijn, M.H.L., Coulson, A.R., Drouin, J., Eperon, I.C., Nierlich, D.P., Roe, B.A., Sanger, F., Schreier, P.H., Smith, A.J.H., Staden, R., and Young, I.G. 1981. Sequence and organization of the Human Mitochondrial Genome. Nature. 290:457-465.

Anderson, S., de Bruijn, M.H.L., Coulson, A.R., Eperon, I.C., Sanger, F., and Young, I.G. 1982. Complete Sequence of Bovine Mitochondrial DNA. J. Mol. Biol. $156: 683-717$.

Aquadro, C.F. and Greenberg, B.D. 1983. Human Mitochondrial DNA Variation and Evolution: Analysis of Nucleotide Sequences from Seven Individuals. Genetics. 103:287312 .

Arnason, U. 1974. Comparative Chromosome studies in Cetacea. Hereditas. $77: 1-36$.

Attardi, G. 1985. Animal Mitochondrial DNA: An Extreme Example of Genetic Economy. In Genome Evolution in Prokaryotes and Eukaryotes, Reanney, D.C. and Chambon, P., eds., Int. Rev. Cyt. 93:93-145.

Avise, J.C., Giblin-Davidson, G., Laerm, J., Patton, J.C., and Lansman, R.A. 1979. Mitochondrial DNA Clones and Matriarchal Phylogeny within and Among Geographic Populations of the Pocket Gopher, Geomys pinetis. Proc. Natl. Acad. Sci. USA. 76:669 $\overline{4-6698}$.

Avise, J.C., Shapira, J.F., Daniel, S.W., Aquadro, C.F., and Lansman, R.A. 1983. Mitochondrial DNA Differentiation During the Speciation Process in Peromyscus. Mol. Biol. Evol. 1:38-56.

Avise, J.C., Bermingham, E., Kessler, L.G., and Saunders, N.C. 1984a. Characterization of Mitochondrial DNA Variability in a Hybrid Swarm Between Subspecies of Bluegill Sunfish. Evolution. 38:931-941. 
Avise, J.C., Neigel, J.E., and Arnold, J. $1984 \mathrm{~b}$. Demographic Influences on Mitochondrial DNA Lineage Survivorship in Animal Populations. J. Mol. Evol. 20:99-105.

Avise, J.C., Arnold, J., Ball, R.M., Bermingham, E., Lamb, T. , Neigel, J.E., Reeb, C.A., and Saunders, N.C. 1987. Intraspecific Phylogeography: The Mitochondrial DNA Bridge Between Population Genetics and Systematics. Ann. Rev. Ecol. Syst. 18:489-522.

Avise, J.C., Ball, R.M., and Arnold, J. 1988. Current Versus Historical Population Sizes in Vertebrate Species with High Gene Flow: A Comparison Based on Mitochondrial DNA Lineages and Inbreeding Theory for Neutral Mutations. Mol. Biol. Evol. 5:331-344.

Balcomb, K.C. III, Boran, J.R., Osborne, R.W., and Haenel, N.J. 1980. Observations of killer whales (Orcinus orca) in Greater Puget sound, state of washington. Report No. MM1300731-7, U.S. Marine Mammal Commission, Washington D.C.

Ball, R.M., Freeman, S., James, F.C., Bermingham, E., and Avise, J.C. 1988. Phylogeographic Population Structure of Red-winged Blackbirds Assessed by Mitochondrial DNA. Proc. Natl. Acad. Sci. USA. $85: 1558-1562$.

Barrell, B.G., Bankier, A.T., and Drouin, J. 1979. A Different Genetic Code in Human Mitochondria. Nature. $282: 189-194$.

Barrell, B.G., Anderson, S., Bankier, A.T., de Bruijn, M.H.L., Chen, E., Coulson, A.R., Drouin, J., Eperon, I.C., Nierlich, D.P., Roe, B.A., Sanger, F., Schreier, P.H., Smith, A.J.H., Staden, R., and Young, I.G. 1980. Different Patterns of Codon Recognition by Mammalian Mitochondrial tRNAs. Proc. Natl. Acad. Sci. USA. $77: 3164-3166$.

Bermingham, E. and Avise, J.C. 1986. Molecular zoogeography of Freshwater Fishes in the Southern United states. Genetics. 113:939-965.

Bibb, M.J., Van Etten, R.A., Wright, C.T., Walberg, M.W., and Clayton, D.A. 1981. Sequence and Gene organization of Mouse Mitochondrial DNA. Cell. $26: 167-180$. 
Bigg, M.A. 1982. An Assessment of Killer Whale (Orcinus orca) Stocks off Vancouver Island, British Columbia. Rep. intl. Whal. Commn. 32:655-666.

Bigg, M.A., Ellis, G.M., Ford, J.K.B., and Balcomb, K.C. 1987. Killer Whales: A study of their Identification, Geneology and Natural History in British Columbia and washington State. Phantom Press and Publ., Inc., Nanaimo, British Columbia, Canada, $79 \mathrm{pp}$.

Bigg, M.A. and Wolman, A.A. 1975. Live-capture Killer whale (Orcinus orca) Fishery, British Columbia and washington, 1962-73. J. Fish. Res. Bd. Can. 32:12131221 .

Bogenhagen, D. and Clayton, D.A. 1974. The Number of Mitochondrial Deoxyribonucleic Acid Genomes in Mouse L and Human HeLa Cells. J. Biol. Chem. 249:7991-7995.

Brooks, J.E. and Roberts, R.J. 1982. Modification Profiles of Bacterial Genomes. Nucleic Acids Res. 10:913-934.

Brown, G.G. and Simpson, M.V. 1982. Novel Features of Animal MtDNA Evolution as shown by sequences of Two Rat Cytochrome Oxidase Subunit II Genes. Proc. Natl. Acad. Sci. USA. 79:3246-3250.

Brown, G.G., Gadaleta, G., Pepe, G., Saccone, C., and Sbisa, E. 1986. Structural Conservation and Variation in the D-loop-containing Region of Vertebrate Mitochondrial DNA. J. Mol. Biol. 192:503-511.

Brown, W.M. 1983. Evolution of Animal Mitochondrial DNA. In Evolution of Genes and Proteins, Nei, M. and Koehn, R.K., eds., Sinauer Associates Inc., Sunderland, Massachusetts, pp. 62-88.

Brown, W.M. 1985. The Mitochondrial Genome of Animals. In Molecular Evolutionary Genetics, Macintyre, R.J., ed., Plenum Press, New York, New York, pp. 95-130.

Brown, W.M., George, Jr., M., and Wilson, A.C. 1979. Rapid Evolution of Animal Mitochondrial DNA. Proc. Natl. Acad. Sci. USA. 76:1967-1971.

Brown, W.M., Prager, E.M., Wang, A., and Wilson, A.C. 1982. Mitochondrial DNA Sequences of Primates: Tempo and Mode of Evolution. J. Mol. Evol. 18:225-239. 
Cann, R.L., Brown, W.M., and Wilson, A.C. 1984. Polymorphic Sites and the Mechanism of Evolution in Human Mitochondrial DNA. Genetics. 106:479-499.

Cann, R.L., Stoneking, M., and wilson, A.C. 1987. Mitochondrial DNA and Human Evolution. Nature. $325: 31-36$.

Cavalier-Smith, T. 1987. Eukaryotes with no Mitochondria. Nature. 326:332-333.

Chomyn, A., Mariottini, P., Cleeter, M., Ragan, F., Matsuno-Yagi, A., Hatefi, Y., Doolittle, R., and Attardi, G. 1985. Six Unidentified Reading Frames of Human Mitochondrial DNA Encode Components of the Respiratory-chain NADH Dehydrogenase. Nature. 314:592-597.

Chomyn, A., Cleeter, W.J., Ragan, C.I., Riley, M., Doolittle, R.F., and Attardi, G. 1986. URF6, Last Unidentified Reading Frame of Human MtDNA, Codes for an NADH Dehydrogenase Subunit. Science. 234:614-618.

Clayton, D.A. 1982. Replication of Animal Mitochondrial DNA. Cel1. 28:693-705.

Clayton, D.A. 1984. Transcription of the Mammalian Mitochondrial Genome. Ann. Rev. Biochem. 53:573-594.

Cornell, L.H. 1983. Hematology and Clinical Chemistry Values in the Killer Whale, Orcinus orca L. J. Wildlife Diseases. 19:259-264.

Cornell, L.H., Duffield, D.A., and Antrim, J.E. 1981. Clinical Applications of Hematological values in Captive Cetaceans. Ann. Proc. Amer. Assoc. Zoo. Vet. $1981: 80-83$.

Dahlheim, M.E., Leatherwood, S., and Perrin, W.F. 1982 . Distribution of Killer whales in the Warm Temperate and Tropical Eastern Pacific. Rep. intl. Whal. Commn. $32: 647-653$.

Dawid, I.B. 1972. Evolution of Mitochondrial DNA Sequences in Xenopus. Dev. Biol. 29:139-151.

de Bruijn, M.H.L., Schreier, P.H., Eperon, I.C., Barrell, B.G., Chen, E.Y., Armstrong, P.W., Wong, J.H.F., and Roe, B.A. 1980. A Mammalian Mitochondrial Serine Transfer RNA Lacking the "Dihydrouridine" Loop and stem. Nucleic Acids Res. 8:5213-5222. 
Doda, J.N., Wright, C.T., and Clayton, D.A. 1981. Elongation of Displacement-loop strands in Human and Mouse Mitochondrial DNA is Arrested Near specific Template Sequences. Proc. Natl. Acad. Sci. USA. $78: 6116-6120$.

Duffield, D.A. 1986. Orcinus orca: Taxonomy, Evolution, Cytogenetics and Population structure. In Behavioral Biology of Killer Whales, Kirkevold, B.C. and Lockard, J.S., eds., Alan R. Liss, Inc., New York, New York, pp. 19-33.

Duffield, D.A., Ridgway, S.H., and Cornell, L.H. 1983. Hematology Distinguishes Coastal and Off-shore Forms of Dolphins (Tursiops). Can. J. Zool. 61:930-933.

Evans, W.E., Yablokov, A.V., and Bowles, A.E. 1982. Geographic Variation in the Color Pattern of Killer Whales (Orcinus orca). Rep. intl. Whal. Commn. $32: 687-694$.

Ford, J.K.B. and Fisher, H.D. 1982. Killer whale (Orcinus orca) Dialects as an Indicator of stocks in British Columbia. Rep. intl. Whal. Commn. 32:671-679.

Ford, J.K.B. and Fisher, H.D. 1983. Group-specific Dialects of Killer Whales (Orcinus orca) in British Columbia. In Communication and Behavior of Whales, Payne, R., ed. A.A.A.S. Selected Symposium 76, Westview Press, Boulder, Colorado, pp. 129-161.

Gauss, D.H., and Sprinzl, M. 1984a. Compilation of tRNA Sequences. Nucleic Acids Res. 12:r1-r58.

Gauss, D.H., and Sprinzl, M. 1984b. Compilation of Sequences of tRNA Genes. Nucleic Acids Res. 12:r59r132.

Giles, R.E., Blanc, H., Cann, H.M., and Wallace, D.C. 1980. Maternal Inheritance of Human Mitochondrial DNA. Proc. Natl. Acad. Sci. USA. 77:6715-6719.

Hall, J.D. and Cornell, L.H. 1986. Killer whales (Orcinus orca) of Prince William Sound, Alaska; Results of 1985 Field Research. Sea World Tech. Contri. 8611C, $35 \mathrm{pp}$. 
Hall, J.D., Donohoe, C.J., and Oeth, P. 1988. A Reanalysis of Proposed Killer whale Ecotypes (Races) from Southern Alaska using Discriminant Function Techniques. In Symposium on the Use of Non-lethal Techniques to Establish Cetacean Population Parameters, NMFS-intl. Whal. Commn. Symp., La Jolla, California, April 19 - May 1, 1988. (Abstract).

Hanahan, D. 1983. Studies on Transformation of Escherichia coli with Plasmids. J. Mol. Biol. 166:557-580.

Heimlich-Boran, S.L. 1986. Cohesive Relationships Among Puget Sound Killer whales. In Behavioral Biology of Killer Whales, Kirkevold, B.C. and Lockard, J.S., eds., Alan R. Liss, Inc., New York, New York, pp. 251-284.

Hixson, J.E. and Brown, W.M. 1986. A Comparison of the Small Ribosomal RNA Genes from the Mitochondrial DNA of the Great Apes and Humans: Sequence, Structure, Evolution and Phylogenetic Implications. Mol. Biol. Evol. $3: 1-18$.

Hixson, J.E., Wong, T.W., and Clayton, D.A. 1986. Both the Conserved stem-loop and Divergent $5^{\prime}$-flanking Sequences are Required for Initiation at the Human Mitochondrial Origin of Light-strand DNA Replication. J. Biol. Chem. 261:2384-2390.

Hoelzel, A.R. and Osborne, R.w. 1986. Killer Whale Call Characteristics: Implications for Cooperative Foraging Strategies. In Behavioral Biology of Killer Whales, Kirkevold, B.C, and Lockard, J.S., eds., Alan R. Liss, Inc., New York, New York, pp. 373-403.

Jones, C.S., Tegelstrom, H., Latchman, D.S., and Berry, R.J. 1988. An Improved Rapid Method for Mitochondrial DNA Isolation Suitable for Use in the study of Closely Related Populations. Biochem. Genet. 26:8388 .

Jukes, T.H. 1983. Evolution of the Amino Acid Code: Inferences from Mitochondrial Codes. J. Mol. Evol. $19: 219-225$.

Kunkel, T.A. and Loeb, L.A. 1981. Fidelity of Mammalian DNA Polymerases. Science. 213:765-767. 
Lansman, R.A., Shade, R.O., Shapira, J.F., and Avise, J.C. 1981. The Use of Restriction Endonucleases to Measure Mitochondrial DNA Sequence Relatedness in Natural Populations. III. Techniques and Potential Applications. J. Mol. Evol. 17:214-226.

Lansman, R.A., Avise, J.C., and Huettel, M.D. 1983. Critical Experimental Test of the Possibility of "Paternal Leakage" of Mitochondrial DNA. Proc. Natl. Acad. Sci. USA. 80:1969-1971.

Lewin, B.M. 1985. Genes. Second Edition. John Wiley and Sons, Inc., New York, New York, $716 \mathrm{pp}$.

Leatherwood, S., Balcomb, K.C., Matkin, C.o., and Ellis, G. 1984. Killer whales (Orcinus orca) of Southern

Alaska; Results of Field Research 1984, Preliminary Report. HSWRI Tech. Rept. \#84-175, 59 pp.

Li, W-H. 1986. Evolutionary Change of Restriction Cleavage Sites and Phylogenetic Inference. Genetics. 113:187213 .

Ljungblad, D.K. and Moore, S.E. 1983. Killer Whales (Orcinus orca) Chasing Gray whales (Eschrichtius robustus) in the Northern Bering Sea. Arctic. 36:361364 .

Lockard, J.S. 1986. Research status of orcinus orca: what is Not known About its Behavioral Biology. In Behavioral Biology of Killer Whales, Kirkevold, B.C. and Lockard, J.S., eds., Alan R. Liss, Inc., New York, New York, pp. 407-442.

Maniatis, T., Fritsch, E.F., and Sambrook, J. 1982. Molecular Cloning. Cold Spring Harbor Laboratory, Cold Spring Harbor, New York, 545 pp.

Mariottini, P., Chomyn, A., and Attardi, G. 1983. Antibodies Against Synthetic Peptides Reveal that the Unidentified Reading Frame $A 6 L$, Overlapping the ATPase 6 Gene, is Expressed in Human Mitochondria. Cell. 32:1269-1277.

Matkin, C.o. and Leatherwood, S. 1986. General Biology of the Killer Whale, orcinus orca: A Synopsis of knowledge. In Behavioral Biology of killer whales, Kirkevold, B.C. and Lockard, J.S., eds., Alan R. Liss, Inc., New York, New York, pp. 35-68. 
Mckusick, V.A. 1987. The Mitochondrial Chromosome. In Genetic Maps 1987: Volume 4, O'Brien, S.J., ed.. Cold spring Harbor Laboratory, cold spring Harbor, New York, pp. 596-597.

Mikhalev, Y.A., Ivashin, M.V., Savusin, V.P., and zelenya, F.E. 1981. The Distribution and Biology of Killer whales in the southern Hemisphere. Rep. intl. Whal. commn. $31: 551-565$.

Mitchell, E. (Editor). 1975. Review of Biology and Fisheries for Smaller Cetaceans. J. Fish. Res. Bd. Can. $32: 875-1240$.

Monnat, R.J. and Loeb, L.A. 1985. Nucleotide sequence Preservation of Human Mitochondrial DNA. Proc. Natl. Acad. Sci. USA. 82:2895-2899.

Nasri, M. and Thomas, D. 1986. Relaxation of Recognition Sequence of Specific Endonuclease HindIII. Nucleic Acids Res. 14:811-821.

Nei, M. and Li, W-H. 1979. Mathematical Model for studying Genetic Variation in Terms of Restriction Endonucleases. Proc. Natl. Acad. Sci. USA. 76:52695273 .

Nei, M. and Tajima, F. 1983. Maximum Likelihood Estimation of the Number of Nucleotide Substitutions from Restriction Sites Data. Genetics. 105:207-217.

Nelson, M, and McClelland, M. 1987. The Effect of Sitespecific Methylation on Restriction-modification Enzymes. Nucleic Acids Res. 15:r219-r230.

Nishiwaki, M. 1972. General Biology. In Mammals of the Sea: Biology and Medicine, Ridgway, S.H., ed., Charles C. Thomas, Springfield, Illinois, pp. 129-132.

Olivo, P.D., Van de Walle, M.J., Laipis, P.J., and Hauswirth, W.W. 1983. Patterns of Base substitution suggest Bovine Mitochondrial DNA D-loop Sequences are Generated by Gene Conversion. Nature. 306:400-402.

Perrin, W.F. (Editor). 1982. Report of the Workshop of Identity, structure and Vital Rates of Killer whale Populations. Rep. intl. Whal. Commn. 32:617-631.

Riggs, M.G. and McLachlan, A. 1986. A Simplified Screening Procedure for Large Numbers of Plasmid Minipreparations. Biotechniques. $4: 312-313$. 
Saccone, C., Attimone1li, M., and Sbisa, E. 1987. structural Elements Highly Preserved During the Evolution of the D-loop-containing Region in Vertebrate Mitochondrial DNA. J. Mol. Evol. 26:205211 .

Shmookler Reis, R.J. and Goldstein, S. 1983. Mitochondrial DNA in Mortal and Immortal Cells. J. Biol. Chem. $258: 9078-9085$.

Southern, E.M. 1975. Detection of Specific Sequences Among DNA Fragments Separated by Gel Electrophoresis. J. Mol. Biol. 98:503-517.

Southern, S.O., Southern, P.J., and Dizon, A.E. 1988. Molecular Characterization of a Cloned Dolphin Mitochondrial Genome. J. Mol. Evol. 28:32-42.

Thomas, W.K., Withler, R.E., and Beckenbach, A.T. 1986. Mitochondrial DNA Analysis of Pacific Salmonid Evolution. Can. J. Zool. 64:1058-1064.

Tzagaloff, A. 1982. Mitochondria. Plenum Press, New York, New York, 342 pp.

Valdez, v. 1961. Echo Sounder Records of Ultrasonic Sounds Made by Killer Whales and Dolphins. Deep-sea Res. $7: 289-290$.

von ziegesar, O., Ellis, G.M., Matkin, C.o., and Goodwin, B. 1986. Sightings of Identifiable Killer whales (Orcinus orca) in Prince William Sound, 1977-83. cetus. $6: 9-13$.

Walberg, M.W. and Clayton, D.A. 1981. Sequence and Properties of the Human KB Cell and Mouse L Cell Dloop Regions of Mitochondrial DNA. Nucleic Acids Res. 9 : 5411-5421.

Whittam, T.S., Clark, A.G., Stoneking, M., Cann, R.L., and Wilson, A.C. 1986. Allelic Variation in Human Mitochondrial Genes Based on Patterns of Restriction Site Polymorphism. Proc. Natl. Acad. Sci. USA. $83: 9611-9615$.

Wilson, A.C., Bush, G.L., Case, S.M., and King, M-C. 1975. Social structuring of Mammalian Populations and Rate of Chromosomal Evolution. Proc. Natl. Acad. Sci. USA. 72:5061-5065. 
Wrischnik, L.A., Higuchi, R.G., Stoneking, M., Erlich, H.A., Arnheim, N., and Wilson, A.C. 1987. Length Mutations in Human Mitochondrial DNA: Direct Sequencing of Enzymatically Amplified DNA. Nucleic Acids Res. 15:529-542. 
APPENDIX A

TOTAL DNA EXTRACTION FROM BLOOD

1) Centrifuge approximately $10 \mathrm{ml}$ whole blood at $1500 \mathrm{xg}$ for $15 \mathrm{~min}$.

2) Transfer upper plasma layer to a new tube.

3) Transfer white cell layer to a new tube.

Plasma Layer

1) Centrifuge plasma layer at $1700 \mathrm{x} g$ for $20 \mathrm{~min}$. to pellet platelets. Discard supernatant.

2) Resuspend platelets in $1.0 \mathrm{ml} \mathrm{STE}(10 \mathrm{mM} \mathrm{Tr}$ is-HCl $\mathrm{pH}$ $8.0,100 \mathrm{mM} \mathrm{NaCl}, 1 \mathrm{mM}$ EDTA pH 8.0).

\section{White Blood Cell Layer}

1) Suspend white cell layer in $0.9 \% \mathrm{NaCl}$ to bring volume up to original volume. Centrifuge at $1400 \mathrm{x} g$ for 15 min. Carefully pipette off upper supernatant.

2) Repeat $\mathrm{NaCl}$ wash until upper supernatant is clear.

3) Resuspend pellet in 5.5 times the pellet volume of cold haemolysis solution $\left(9: 10.144 \mathrm{M} \mathrm{NH}_{4} \mathrm{Cl}: 0.01 \mathrm{M} \mathrm{NH}_{4} \mathrm{HCO}_{3}\right)$.

4) Place at $-20^{\circ} \mathrm{C}$ for $3 \mathrm{~min}$. until colour turns from red to wine. Centrifuge at $1400 \times \mathrm{g}$ for $20 \mathrm{~min}$. Discard supernatant.

5) Repeat haemolysis step until red blood cell contamination is negligible.

6) Transfer platelet solution to white cell tube. Suspend white cell pellet in solution.

7) Rinse platelet tube with $1.0 \mathrm{ml} \mathrm{STE}$ and transfer to white cell solution.

8) Add STE to solution to bring volume up to $6.0 \mathrm{ml}$. 
9) Add $500 \mu \mathrm{l}$ proteinase $\mathrm{K}(1 \mathrm{mg} / \mathrm{ml}$ in water) while $\mathrm{mixing}$ gently. Slowly add $200 \mu 125 \%$ SDS while mixing gently. Incubate at $37^{\circ} \mathrm{C} 16-20$ hours.

10) Add an equal volume of Tris-buffered phenol chloroform isoamyl alcohol (PCIA; prepared according to Maniatis et al. 1982). Mix gently for $15 \mathrm{~min}$. Centrifuge at $1600 \times \mathrm{g}$ for $20 \mathrm{~min}$. Remove upper DNA layer to a new tube.

11) Repeat PCIA extraction two more times.

12) Repeat above extraction twice using chloroform isoamy 1 alcohol (CIA; $24: 1 \mathrm{v} / \mathrm{v}$ ).

13) Add $1 / 10$ volume $3.0 \mathrm{M}$ sodium acetate $(\mathrm{pH} 5.2)$. Add three volumes cold absolute ethanol.

14) Place at $-20^{\circ} \mathrm{C}$ for one hour to overnight to precipitate DNA.

15) Centrifuge at $12,000 \times \mathrm{g}$ for $40-50 \mathrm{~min}$. at $4^{\circ} \mathrm{C}$. Discard supernatant.

16) Rinse tube with $1.0 \mathrm{ml} 75 \%$ ethanol to remove excess salts. Centrifuge at $12,000 \mathrm{xg}$ for $20 \mathrm{~min}$. Discard supernatant.

17) Vacuum dry pellet until all trace of ethanol is gone.

18) Resuspend pellet in TE (10 mM Tris-HCl pH $8.0,1 \mathrm{mM}$ EDTA pH 8.0). 
APPENDIX B

MITOCHONDRIAL DNA EXTRACTION FROM BLOOD

1) Centrifuge approximately $10 \mathrm{ml}$ whole blood at $1500 \mathrm{xg}$ for $15 \mathrm{~min}$.

2) Transfer upper plasma layer to a new tube.

3) Transfer white cell layer to a new tube.

White Cell Layer

1) Suspend white cell layer in four volumes of homogenization solution $(0.25 \mathrm{M}$ sucrose, $10 \mathrm{mM}$ Tris-HCl pH 7.5, 1 mM EDTA pH 7.5).

2) Pour into a Dounce homogenizer (with B type pestle). Disrupt cells with five strokes of homogenizer. Pour solution into a new tube.

3) Centrifuge at $500 \times \mathrm{g}$ for $5 \mathrm{~min}$. at $4^{\circ} \mathrm{C}$ to pellet cell debris. Carefully remove supernatant with a pipette to a new tube.

4) Repeat step 3 until the resultant pellet is negligible.

5) Centrifuge at $12,000 \times \mathrm{g}$ for $20 \mathrm{~min}$. at $20^{\circ} \mathrm{C}$ to pellet mitochondria. Discard supernatant.

Plasma Layer

1) Centrifuge plasma layer at $1000 \times \mathrm{g}$ for $20 \mathrm{~min}$. to pellet platelets. Discard supernatant. Resuspend platelets in $0.7 \mathrm{ml}$ TE $(10 \mathrm{mM}$ Tris-HCl pH $8.0,1 \mathrm{mM}$ EDTA pH 8.0).

2) Transfer platelet solution to tube containing white cell mitochondria and suspend pellet.

3) Add $10.0 \mu 1$ of $25 \%$ SDS while mixing gently. Incubate for $10 \mathrm{~min}$. at $37^{\circ} \mathrm{C}$.

4) Add $15.0 \mu 1$ of $5.0 \mathrm{M} \mathrm{NaCl}$. Transfer sample to one or two eppendorf tubes. 
5) Add an equal volume of Tris-buffered phenol chloroform isoamyl alcohol (PCIA; prepared according to Maniatis et al. 1982). Mix gently for $15 \mathrm{~min}$. Centrifuge in microcentrifuge at $12,000 \times \mathrm{g}$ for $5 \mathrm{~min}$. Remove upper DNA layer to a new tube.

6) Repeat PCIA extraction.

7) Repeat above extraction using chloroform isoamyl alcohol (CIA; 24:1 v/v).

8) Add 1/10 volume $3.0 \mathrm{M}$ sodium acetate ( $\mathrm{pH} 5.2$ ). Add three volumes of cold absolute ethanol.

9) Place at $-20^{\circ} \mathrm{C}$ until DNA is precipitated (approximately one hour).

10) Centrifuge in microcentrifuge at $12,000 \mathrm{x}$ for $30 \mathrm{~min}$. at $4^{\circ} \mathrm{C}$. Discard supernatant.

11) Rinse tube with $500 \mu 175 \%$ ethanol to remove excess salts. Centrifuge at $12,000 \times \mathrm{g}$ for $15 \mathrm{~min}$. Discard supernatant.

12) vacuum dry pellet until all trace of ethanol is gone.

13) Resuspend pellet in TE (pH 8.0). 
APPENDIX C

RAPID MITOCHONDRIAL DNA ISOLATION FROM TISSUE

1) Weigh out approximately 5 grams of tissue. It can be fresh or frozen muscle, liver or kidney. Cut tissue into very small pieces with a pair of sterile scissors.

2) Place $20 \mathrm{ml}$ cold homogenization solution $10.21 \mathrm{M}$ mannitol, $70 \mathrm{mM}$ sucrose, $50 \mathrm{mM}$ Tris-HCl pH $7.5,3 \mathrm{mM}$ $\mathrm{CaCl}^{2}$, $10 \mathrm{mM}$ EDTA $\left.\mathrm{pH} 7.5\right)$ into cold homogenization tube and add tissue.

3) Homogenize tissue* using a motor-driven glass Teflon homogenizer. The clearance between pestle and tube should be about $0.2 \mathrm{~mm}$ and the homogenization speed should be approximately $200 \mathrm{rpm}$.

4) Pour homogenate into a cold tube.

5) Centrifuge at $1000 \mathrm{x}$ for $15 \mathrm{~min}$. at $4^{\circ} \mathrm{C}$ to pellet cell debris and nuclei. Carefully pipette supernatant to a new tube and place on ice.

6) Resuspend the nuclear pellet in $5.0 \mathrm{ml}$ homogenization solution. Centrifuge at $1300 \times \mathrm{g}$ for $10 \mathrm{~min}$. at $4^{\circ} \mathrm{C}$. Pipette off the supernatant and add it to the tube that is on ice.

7) Centrifuge supernatant at $1300 \mathrm{x}$ g for $10 \mathrm{~min}$. at $4^{\circ} \mathrm{C}$. Pipette off supernatant to a new tube. Repeat spins until there is no visible nuclear pellet left.

8) Centrifuge the final supernatant at $12,000 \mathrm{x} \mathrm{g}$ for 30 min. at $4^{\circ} \mathrm{C}$ to pellet the mitochondria. Discard supernatant.

9) Resuspend mitochondrial pellet in $5.0 \mathrm{ml} \mathrm{STE}(10 \mathrm{mM}$ Tris-HCl pH 8.0, $100 \mathrm{mM} \mathrm{NaCl}, 1 \mathrm{mM}$ EDTA pH 8.0). Add $250 \mu 125 \%$ SDS, mix gently. Add $400 \mu 1$ proteinase $K$ ( 1 $\mathrm{mg} / \mathrm{ml}$ in water), mix gently.

10) Incubate at $37^{\circ} \mathrm{C} 16-20$ hours. 
11) Add an equal volume of Tris-buffered phenol chloroform isoamyl alcohol (PCIA; prepared according to Maniatis et al. 1982). Mix gently for $15 \mathrm{~min}$. Centrifuge at $1600 \times \mathrm{g}$ for $20 \mathrm{~min}$. Transfer upper DNA layer to a new tube.

12) Repeat PCIA extraction two more times.

13) Repeat above extraction twice using chloroform isoamyl alcohol (CIA; 24:1 v/v).

14) Add $1 / 10$ volume $3.0 \mathrm{M}$ sodium acetate ( $\mathrm{pH} 5.2)$. Add three volumes cold absolute ethanol.

15) Place at $-20^{\circ} \mathrm{C}$ for one hour to overnight to precipitate DNA.

16) Centrifuge at $12,000 \mathrm{x}$ g for $40-50 \mathrm{~min}$. at $4{ }^{\circ} \mathrm{C}$. Discard supernatant.

17) Rinse tube with $1.0 \mathrm{~m} l 75$ \% ethanol to remove excess salts. Centrifuge at $12,000 \mathrm{x} \mathrm{g}$ for $20 \mathrm{~min}$. at $4^{\circ} \mathrm{C}$. Discard supernatant.

18) Vacuum dry pellet until all trace of ethanol is gone.

19) Resuspend pellet in TE (10 mM Tris-HCl pH $8.0,1 \mathrm{mM}$ EDTA pH 8.0).

* I found that due to the large amount of connective tissue present in killer whale muscle and liver, more efficient homogenization was attainable if the tissue was homogenized in small aliquots using approximately 10 strokes of the pestle. The aliquots can then be added together during step 5 . 
APPENDIX D

\section{TRANSFORMATION}

1) Grow a $1.0 \mathrm{ml}$ overnight culture of appropriate E. coli cells in sterile Luria-Bertani medium (LB; Maniatis et al. 1982) at $37^{\circ} \mathrm{C}$ with vigorous shaking.

2) Inoculate overnight culture into fresh LB the next day at a concentration of $1: 100$ (i.e. $0.5 \mathrm{ml}$ culture into $50.0 \mathrm{ml} \mathrm{LB}$ ).

3) Incubate at $37^{\circ} \mathrm{C}$ with vigorous shaking until cells have reached the beginning of the plateau phase of growth. Take OD600 readings of $1 \mathrm{ml}$ aliquots after one hour of incubation, and every hour or $30 \mathrm{~min}$. thereafter until plateau phase is reached. Discard aliquots after use. OD600 should be between $0.3-0.8$ and usually takes 2-4 hours.

4) Pellet cells in $50 \mathrm{ml}$ centrifuge tubes by centrifuging at $2000 \mathrm{x} \mathrm{g}$ for $20 \mathrm{~min}$. at $4^{\circ} \mathrm{C}$. Discard supernatant.

5) Wash pellet in $1 / 2$ growth volume of cold, filter sterilized transformation wash buffer $(10 \mathrm{mM} \mathrm{NaCl}, 5 \mathrm{mM}$ Tris-HCl $\mathrm{pH} 8.0,5 \mathrm{mM} \mathrm{MgCl}_{2}$ ).

6) Centrifuge at $2000 \times \mathrm{g}$ for $15 \mathrm{~min}$. at $4{ }^{\circ} \mathrm{C}$. Discard supernatant.

7) Resuspend pellet in $1 / 2$ growth volume of cold, filter sterilized transformation buffer $(30 \mathrm{mM} \mathrm{CaCl}, 5 \mathrm{mM}$ $\mathrm{MgCl}_{2}, 5 \mathrm{mM}$ Tris-HCl $\left.\mathrm{pH} 8.0\right)$.

8) Place cells on ice for $20 \mathrm{~min}$.

9) Centrifuge at $2000 \mathrm{x}$ g for $15 \mathrm{~min}$. at $4^{\circ} \mathrm{C}$. Discard supernatant.

10) Resuspend cells in $1 / 10$ growth volume of cold transformation buffer. 
11) Place $200 \mu 1$ of cells into an eppendorf tube. Gently mix in 0.03-0.1 $\mu \mathrm{g}$ of DNA to be inserted. DNA should be in no greater a volume than $10 \mu \mathrm{l}$. Remember a negative control.

12) Place on ice for $60 \mathrm{~min}$.

13) Heat shock cells by placing in $42^{\circ} \mathrm{C}$ water bath for 2 min.

14) Add $600 \mu 1$ LB.

15) Place in $37^{\circ} \mathrm{C}$ water bath for $30 \mathrm{~min}$. to allow for antibiotic expression.

16) Remove $40 \mu 1$ from tube and streak out on appropriate antibiotic plates (prepared according to Maniatis et al. 1982).

17) Pellet remaining cells in microcentrifuge. This usually takes less than $1 \mathrm{~min}$. Discard supernatant.

18) Resuspend cells in $40 \mu \mathrm{LB}$, plate out on antibiotic plates.

19) Incubate inverted plates overnight at $37^{\circ} \mathrm{C}$.

20) Examine the plates the next day for the presence of transformed colonies. 


\author{
APPENDIX E
}

\title{
PLASMID PREPARATION
}

1) Grow a $10 \mathrm{ml}$ overnight culture of E. coli cells containing the desired plasmid in sterile Luria-Bertani medium (LB; Maniatis et al. 1982) containing the appropriate antibiotic at $37^{\circ} \mathrm{C}$ with vigorous shaking.

2) Inoculate l litre of sterile LB containing the appropriate antibiotic with overnight culture.

3) Incubate at $37^{\circ} \mathrm{C}$ with vigorous shaking until cells have reached the plateau phase of growth. Take OD600 readings after 2 hours of incubation and every $30 \mathrm{~min}$. thereafter until plateau phase is just reached (around OD 600 of $0.6-0.9)$.

4) Add $5.0 \mathrm{ml}$ chloramphenicol (34 mg/ml in ethanol) to inhibit protein synthesis of host DNA while leaving replication of plasmids unaffected. If stringent plasmids such as pACYC 184 are being grown, disregard steps 3 and 4 .

5) Continue to incubate culture a further 15-20 hours.

6) Place culture on ice.

7) Pour cell culture into a $250 \mathrm{ml}$ centrifuge bottle. Centrifuge at $0^{\circ} \mathrm{C}$ at $6000 \mathrm{rpm}$ for $10 \mathrm{~min}$. Discard supernatant.

8) Continue to add cell culture and centrifuge until all of the culture has been pelleted into the centrifuge bottle.

9) Place bottle on ice.

10) Resuspend pellet in $1.0 \mathrm{ml}$ of solution I $(50 \mathrm{mM}$ glucose, $10 \mathrm{mM}$ EDTA pH 8.0, $25 \mathrm{mM}$ Tris-HCl pH 8.0).

11) Add $9.0 \mathrm{ml}$ of freshly made solution I containing $10 \mathrm{mg}$ of lysozyme. Stir until mixed. Incubate on ice for 10 min. or until solution becomes viscous and slimy. The cell membranes are disrupted by the action of the lysozyme, causing the cell contents to be released. 
12) Add $20.0 \mathrm{ml}$ of solution II (1.0\% SDS, $0.2 \mathrm{~N} \mathrm{NaOH).}$ Incubate on ice with occasional stirring for 10 min. or until solution clears. Lysozyme is inactivated and proteins are bound.

13) Add $15.0 \mathrm{ml}$ of cold solution III $(3.0 \mathrm{M}$ potassium acetate, $1.8 \mathrm{M}$ formic acid) and stir until a white precipitate of proteins, SDS and nuclear DNA forms.

14) Incubate on ice for $15 \mathrm{~min}$. with occasional stirring.

15) Centrifuge at $8000 \mathrm{rpm}$ for $15 \mathrm{~min}$. at $0^{\circ} \mathrm{C}$ to pellet precipitate.

16) Pour supernatant through several layers of sterile gauze into new $250 \mathrm{ml}$ bottles to strain out white precipitate.

17) Add one volume ( $45 \mathrm{ml})$ of isopropanol and incubate at room temperature for $20 \mathrm{~min}$. to precipitate plasmid DNA.

18) Centrifuge at $8000 \mathrm{rpm}$ for $30 \mathrm{~min}$. at $20^{\circ} \mathrm{C}$ to pellet DNA. Discard supernatant. Let pellet drain dry.

19) Resuspend pellet in $3.9 \mathrm{ml}$ per gradient $(7.8 \mathrm{ml})$ of $5 \mathrm{x}$ TE (50 mM Tris-HCl pH 8.0, $5 \mathrm{mM}$ EDTA pH 8.0). Transfer solution to two quickseal tubes.

20) Rinse bottle with $1.6 \mathrm{ml}$ per gradient $(3.2 \mathrm{ml})$ of cesium chloride-saturated $5 \mathrm{X} \mathrm{TE}$ and transfer to a new tube.

21) Add $0.27 \mathrm{ml}$ ethidium bromide $(10 \mathrm{mg} / \mathrm{ml})$ to tube, and mix contents. Transfer half to each quickseal tube and mix.

22) Underlay solution with $6.5 \mathrm{ml}$ per gradient of cesium chloride-saturated $5 \mathrm{X}$ TE.

23) Seal tubes. Load into Ti50 rotor and centrifuge in a vacuum centrifuge at $42,000 \mathrm{rpm}$ for at least 36 hours at $20^{\circ} \mathrm{C}$.

24) Collect form I DNA from gradient by visualization under longwave ultraviolet (UV) light. Puncture tube just beneath the lower band with an 18-gauge needle connected to a $5 \mathrm{cc}$ syringe and slowly draw band into syringe. Remove needle and transfer DNA to a new tube. 
25) Extract DNA with butanol to remove ethidium bromide. Add an equal volume of TE-saturated butanol. Mix gently. Let layers develop. Remove upper butanolethidium bromide layer and discard. Repeat extraction two more times.

26) Extract two times with unsaturated butanol or until all trace of ethidium bromide is gone.

27) Add two volumes of sterile distilled water to dilute the cesium chloride.

28) Add three volumes of cold absolute ethanol and place at $-20^{\circ} \mathrm{C}$ for 1 hour to overnight to precipitate the DNA.

29) Centrifuge at $12,000 \times \mathrm{g}$ for $45 \mathrm{~min}$. to pellet DNA. Discard supernatant.

30) Rinse tube with 75\% ethanol and centrifuge at $12,000 \times$ $g$ for 30 min. Discard supernatant.

31) Vacuum dry pellet until all trace of ethanol is gone.

32) Resuspend DNA in 200-500 $\mu \mathrm{l}$ TE (10 mM Tris-HCl pH 8.0, 1 mM EDTA pH 8.0).

If desired, tRNA can be removed by the following method:

1) Adjust volume of DNA sample to $1.0 \mathrm{ml}$ with TE. Add $\mathrm{NaCl}$ to sample to a final concentration of $100 \mathrm{~mm}$.

2) Layer DNA sample on a $1 \times 10 \mathrm{~cm}$ column of STEequilibrated Bio-Gel A-150. (STE: $10 \mathrm{mM}$ Tris-HCl pH 8.0, $100 \mathrm{mM} \mathrm{NaCl}, 1 \mathrm{mM}$ EDTA pH 8.0).

3) Allow sample to run into column. Apply a reservior of STE on top of column, taking care to never allow top of column to dry.

4) Immediately begin to collect $0.5 \mathrm{ml}$ fractions. The flow rate should be adjusted such that each fraction takes $5 \mathrm{~min}$. to run out of column. It is best to adjust the flow rate using STE prior to application of DNA sample. 
5) When 20 fractions have been collected, clamp off the bottom of the column.

6) Analyze $10.0 \mu 1$ of each fraction by electrophoresis through a $1.0 \%$ agarose gel followed by ethidium bromide staining and UV visualization (see Maniatis et al. 1982).

7) Pool the fractions that contain plasmid DNA only.

8) Add $1 / 10$ volume $3.0 \mathrm{M}$ sodium acetate ( $\mathrm{pH} 5.2$ ).

9) Precipitate the DNA following steps 28-32 above. 
APPENDIX F

\section{SPUN COLUMN PROCEDURE}

1) Plug the bottom of a sterile 1 cc syringe with sterile, siliconized glass wool.

2) Fill syringe with Sephadex $G-50$ beads that have been equilibrated with TE ( $10 \mathrm{mM}$ Tris-HCl pH $8.0,1 \mathrm{mM}$ EDTA $\mathrm{pH}$ 8.0).

3) Place syringe in a centrifuge tube so that the tip of the syringe hangs freely inside the tube.

4) Centrifuge in a swinging bucket rotor exactly 2 min. at $500 \mathrm{x} \mathrm{g}$. Make sure all spins are exactly the same length of time and speed.

5) Add more TE-bead mix to top of column. Centrifuge as above. Repeat until the packed column volume is $0.9 \mathrm{cc}$.

6) Wash the column five times by applying TE to fill the syringe and centrifuging as above.

7) Wash the column three times with TE using the exact volume as the sample and centrifuging as above.

8) Place an eppendorf tube into bottom of centrifuge tube and put tip of syringe into eppendorf tube.

9) Apply sample to top of column. Centrifuge as above.

10) Remove eppendorf tube containing the sample.

11) Place another eppendorf tube inside centrifuge tube.

12) Add exact volume of $T E$ as sample was to column. Centrifuge as above.

13) Remove eppendorf tube containing TE rinse. Retain final TE rinse and column until you have verified the presence of your sample in the first tube by TCA precipitation. 
APPENDIX G

TRICHLOROACETIC ACID PRECIPITATION OF NUCLEIC ACIDS

1) Spot $1.0 \mu l$ of reaction mixture onto a $2 \mathrm{~cm}$ circle of glass fibre chromatography filter paper at the following times during the nick translation procedure: twice just prior to the addition of DNA polymerase I (one circle will be subject to TCA precipitation and one will not), once after termination of the reaction and once after sephadex G-50 column separation.

2) After spotting the sample onto the filter, spot water onto the filter several times to rinse the pipette tip and ensure that all of the reaction mixture gets onto the filter.

3) Place one of the filters taken before the start of the reaction aside.

4) Rinse the other three filters twice in cold $5 \%$ TCA $/ 0.02$ $M$ sodium pyrophosphate for $5 \mathrm{~min}$. on ice to precipitate the DNA onto the filters. Unincorporated nucleotides will not precipitate onto the filters.

5) Rinse the filters three times with cold $5 \%$ TCA for 5 min. on ice.

6) Rinse the filters three times with cold absolute ethanol. Ethanol aids in drying of the filters.

7) Allow filters to dry completely.

8) Place all four filters into labelled scintillation vials. Add $5.0 \mathrm{ml}$ of scintillation fluid. Make sure filters are completely submerged.

9) Run samples through a scintillation counter.

10) Calculate the amount of ${ }^{32} \mathrm{P}$ incorporated into the sample. 
APPENDIX H

\section{SOUTHERN TRANSFER}

All solutions required for Southern transfer are listed at the end of this protocol.

1) Run restricted DNA samples on a horizontal agarose gel.

2) If you wish to determine whether samples ran correctly on the gel, stain gel with $40 \mu l$ ethidium bromide $(10$ $\mathrm{mg} / \mathrm{ml}$ ) in $500 \mathrm{ml}$ distilled water with shaking for approximately $5 \mathrm{~min}$. Destain in $500 \mathrm{ml}$ distilled water for approximately $1 / 2$ to 1 hour. Examine gel under longwave UV light.

3) Cover gel with $0.25 \mathrm{M} \mathrm{HCl}$ solution and agitate slowly for $45 \mathrm{~min}$. or until bromophenol blue dye turns yellow. Decant solution.

4) Add denaturing solution to cover gel, agitate slowly for 45 min. Decant solution.

5) Add neutralizing solution to cover gel, agitate slowly for $45 \mathrm{~min}$. Decant solution.

6) Blot gel dry.

7) Wet a piece of whatman 3MM filter paper with distilled water. The paper should be the same width as gel, but long enough to form a wick between the buffer reservoirs.

8) Place filter paper in gel rig, making sure no air bubbles are trapped underneath.

9) Place gel upside down on top of filter paper, making sure no air bubbles are trapped underneath.

10) Carefully place nylon membrane on gel where transfer is to occur, making sure no air bubbles are trapped underneath. 
11) Place two pieces of wet whatmann $3 M M$ filter paper on top of membrane, making sure no air bubbles are trapped underneath. The filter paper should be the exact size of the gel.

12) Stack single-fold paper towels on top of paper $14-5 \mathrm{~cm}$ in height) without trapping air bubbles.

13) Weigh down apparatus by placing a pyrex dish filled with water on top of the paper towels.

14) Add $20 x$ SSC to buffer reservoirs so that the ends of the filter paper are immersed in buffer.

15) Allow transfer to proceed for 12-14 hours.

16) Rinse membrane with $2 x$ SSC to remove any adhering agarose.

17) Place membrane on Saran wrap, allow to dry completely.

18) Wrap membrane in Saran Wrap and place DNA side down on a longwave UV transilluminator for eight min. to crosslink DNA to membrane.

19) Place membrane in hybridization bag, heat seal bag. cut off one corner of bag.

20) Add 25 ml of pre-hybridization solution containing denatured sheared salmon sperm DNA. Solution should be heated to $37^{\circ} \mathrm{C}$ just prior to use.

21) Remove air bubbles from bag by carefully running a ruler along membrane (try not to lose any solution).

22) Heat seal corner of bag.

23) Place in a $65^{\circ} \mathrm{C}$ water bath-shaker for 2 hours to overnight.

24) Mix heat-treated probe with $25 \mathrm{ml}$ pre-hybridization buffer that has been heated to $37^{\circ} \mathrm{C}$.

25) Cut off corner of hybridization bag and pour out prehybridization solution.

26) Add hybridization solution; remove air bubbles; heat seal the bag.

27) Place in a $65^{\circ} \mathrm{C}$ water bath-shaker for at least 12 hours. 
28) Remove membrane from bag. Hybridization solution can be kept for later re-use by sealing it in bag and storing at $-20^{\circ} \mathrm{C}$.

29) Incubate membrane with $50 \mathrm{ml} 2 \mathrm{x} \mathrm{sSC}$ at $65^{\circ} \mathrm{C}$ for $15 \mathrm{~min}$. This step can be done in a new hybridization bag, or in a tight-fitting sealed container.

30) Replace with $50 \mathrm{ml} 2 \mathrm{x} \mathrm{SSC} / 0.1 \% \mathrm{SDS}$ and incubate at $65^{\circ} \mathrm{C}$ for $30 \mathrm{~min}$.

31) Replace with $50 \mathrm{ml} 1 \mathrm{XSSC} / 0.1 \% \mathrm{SDS}$ and incubate at $65^{\circ} \mathrm{C}$ for $10 \mathrm{~min}$.

32) Briefly rinse membrane with $2 x$ sSC.

33) Cover membrane with Buffer 1 and slowly agitate at room temperature for $1 \mathrm{~min}$.

34) Incubate membrane in $30 \mathrm{ml}$ Buffer 2 at $65^{\circ} \mathrm{C}$ for 1 hour.

35) Place membrane in plastic container.

36) Pour SA-AP solution over membrane.

37) Gently agitate by hand for $10 \mathrm{~min}$. at room temperature. occasionally turn over membrane with forceps to ensure complete coverage of membrane with solution.

38) Decant solution.

39) Wash membrane with 20-fold excess of Buffer 1 than used during SA-AP conjugation. Gently agitate for 15 min. at room temperature. Decant solution.

40) Repeat wash step.

41) Wash membrane in a 10-fold excess of Buffer 3 than used during SA-AP conjugation. Gently agitate for 10 min. at room temperature. Decant solution.

42) Place membrane in hybridization bag; heat seal; cut off corner of bag.

43) Add dye solution.

44) Remove air bubbles, heat seal corner of bag.

45) Invert bag to cover membrane with solution. 
46) Place membrane in the dark to allow color development to proceed. During color development, invert bag occasionally. It should take $1 / 2$ to 3 hours for complete development to occur. Longer incubations may result in increased background.

47) Remove membrane from bag and place in a plastic container.

48) Add termination solution to cover membrane.

49) Gently agitate for $10 \mathrm{~min}$. at room temperature.

50) Place membrane on Saran Wrap and allow to dry completely.

51) Photograph membrane.

52) Store membrane wrapped in saran Wrap. Keep membrane in the dark as much as possible, as light will cause the development of excess background.

Solutions Required for Southern Transfer Procedure

All solutions should be prepared with sterile, twice distilled water.

$0.25 \mathrm{M} \mathrm{HCl}$

Denaturing solution

$1.5 \mathrm{M} \mathrm{NaCl}$

$0.5 \mathrm{M} \mathrm{NaOH}$

Neutralizing solution

$1.5 \mathrm{M} \mathrm{NaCl}$

$0.5 \mathrm{M}$ Tris-HCl, $\mathrm{pH} 7.2$

$1.0 \mathrm{mM}$ EDTA, pH 7.2

$20 \mathrm{XSC}$

$3.0 \mathrm{M} \mathrm{NaCl}$

0.3 M sodium citrate

Adjust pH to 7.0 with $1.0 \mathrm{M} \mathrm{HCl}$ and autoclave.

Pre-hybridization solution

$6 \mathrm{X}$ SSC

$5 \mathrm{X}$ Denhardt's solution

$0.5 \%(w / v)$ SDS

Prepare just prior to use. 
Denhardt's solution, $100 \mathrm{x}$

$10 \mathrm{~g}$ polyvinylpyrrolidone

$10 \mathrm{~g}$ bovine serum albumin (Fraction $\mathrm{V}$ )

$10 \mathrm{~g}$ Ficoll 400

sterile water to $500 \mathrm{ml}$

Filter sterilize through $0.45 \mu \mathrm{m}$ filter, store refrigerated.

Denatured sheared salmon sperm DNA

Prepare a $10.0 \mathrm{mg} / \mathrm{ml}$ solution of salmon sperm DNA in water. Shear the DNA by forcing it through an 18gauge needle four times. Place in a boiling water bath for $10 \mathrm{~min}$. and store refrigerated. Just before use, heat the DNA for $5 \mathrm{~min}$. in a boiling water bath. Chill quickly on ice. Add $50.0 \mu 1$ to pre-hybridization solution just before adding to membrane.

Denatured probe DNA

Denature labelled probe DNA by heating in a boiling water bath for 5 min. just before use. Chill quickly on ice and add to pre-hybridization solution just before adding to membrane.

$2 \times \operatorname{ssc}$

$2 \times \operatorname{ssc} / 0.18(\mathrm{w} / \mathrm{v}) \operatorname{SDS}$

$1 \mathrm{XSSC} / 0.18(\mathrm{w} / \mathrm{v}) \operatorname{SDS}$

Buffer 1

$0.1 \mathrm{M}$ Tris-HCl, $\mathrm{pH} 7.5$

$0.15 \mathrm{M} \mathrm{NaCl}$

Buffer 2

$38(w / v)$ bovine serum albumin (Fraction $v)$ in Buffer 1.

Buffer 3

$0.1 \mathrm{M}$ Tris-HCl, $\mathrm{pH} 9.5$

$0.1 \mathrm{M} \mathrm{NaCl}$

$50 \mathrm{mM} \mathrm{MgCl} 2$

SA-AP solution

Prepare a $1.0 \mathrm{\mu g} / \mathrm{ml}$ sqlution in Buffer 1 just prior to use. Make $0.07 \mathrm{ml} / \mathrm{cm}^{2}$ of filter. For a $10 \mathrm{x} 15 \mathrm{~cm}$ membrane, mix $10.0 \mathrm{ml}$ Buffer 1 with $10.0 \mu \mathrm{l}$ SA-AP. 
Dye solution

$7.5 \mathrm{ml}$ Buffer 3

$33.0 \mu 1$ NBT

Invert solution gently.

Add $25.0 \mu 1$ BCIP.

Invert solution gently.

Make solution just prior to use.

Termination solution

$20 \mathrm{mM}$ Tris-HCl, $\mathrm{pH} 7.5$

$0.5 \mathrm{mM}$ EDTA pH 7.5 